\title{
Ayla Kutlu'nun Kaçış romanında modernist izlekler
}

\section{Yaşar ŞİMŞEK ${ }^{1}$}

APA: Şimşek, Y. (2020). Ayla Kutlu'nun Kaçış romanında modernist izlekler. RumeliDE Dil ve Edebiyat Araştırmaları Dergisi, (20), 218-241. DOI: 10.29000/rumelide.791380.

\section{$\ddot{\mathbf{O} z}$}

1970’lerin ikinci yarısında kitap tanıtım yazılarıyla edebiyat dünyasına adım atan Ayla Kutlu, Türk edebiyatında romanları, öyküleri ve çocuklara yönelik yazdığı kitaplar ile tanınmıştır. Yazar, Türkiye'nin tarihsel süreç içinde geçirdiği toplumsal ve siyasal değişimleri işlediği roman ve öykülerinde ülkenin belirli dönemlerine ışık tutmuştur. Gelenek ile modernizmin yansımalarına birlikte yer verdiği eserlerinde belgin dili, gözlem gücü ve psikolojik tahlilleriyle dikkati çekmiştir. Aynı zamanda siyasi çatışmalar, toplumsal çalkantılar ve sosyal meseleler içinde sarsılan bireyi ve onun bunalımını ele almıştır. Yazarın 1979'da yayınlanan Kaçış romanı da toplumsal meseleler ve geleneksel olgular etrafında modern bireyin serüvenini ve bunalımını anlatmaktadır. Romanda modern hayat dolayımında kişilerin korkuları, çatışmaları ve ruhsal durumları ortaya konulur. Yazar, bütün bunları yaparken modernist romana özgü kavram ve izleklere eserinde yer verir. Bu anlamda romanda sorgulama, bunalım, kaçış, yalnızlık, yabancılaşma, belirsizlik gibi izlekler etrafında modern bireyin açmazları anlatılır. Bu çalışmada Ayla Kutlu'nun Kaçış romanı, modernizmin yansımaları bağlamında modernist romana özgü izlekler açısından incelenmiştir. Yazıda öncelikle modernizm, modernist sanat ve modernist roman hakkında bilgi verilmiş, modernist romanın içerik, anlatım ve teknik özellikleri üzerinde durulmuştur. Ardından yazarın sanat yaşamı ve eserleri hakkında kısa bir bilgi verilerek modernist romana ilgisine ve eğilimine değinilmiştir. Sonrasında yazıya konu olan Kaçış romanı, modernist izlekler bağlamında çeşitli başlıklar altında değerlendirilmiştir. Sonuç kısmında elde edilen bulgular ışığında romanın içeriğine ve izleksel yönüne dair bir değerlendirme yapılmıştır. Kişilerin merkeze alındığı bir roman olan Kaçış, modern birey(ler)in psikolojik durumunu ve karmaşık hallerini yansıtan ve bunları da kaçış, bunalım, yabancılaşma, yalnızlık, sorgulama, belirsizlik, iletişimsizlik, korku ve kuşku gibi modernist romana özgü izlekler üzerinden işleyen bir eser hüviyeti taşımaktadır.

Anahtar kelimeler: Ayla Kutlu, Kaçış, modernizm, modernist roman, izlek, birey

\section{Modernist themes in Ayla Kutlu's Kaçış (Escape)}

\begin{abstract}
Ayla Kutlu, who stepped into the world of literature with her blurbs in the second half of the 1970s, is known for her novels, stories, and books for children in Turkish literature. The author sheds light on specific periods of Turkey in her novels and stories, in which she discusses the social and political changes that Turkey has undergone during its historical process. In her works, which include the reflections of tradition and modernism together, she attracts attention with her clear language, observation power, and psychological analyses. She also describes the individual and her/his crisis, who is shaken by political conflicts, social turmoil, and issues. Her novel, Kaçış (Escape), published

Dr. Öğr. Üyesi, Gaziosmanpaşa Üniversitesi, Eğitim Fakültesi, Türkçe ve Sosyal Bilimler Eğitimi Bölümü (Tokat, Türkiye) yasar.simsek@gop.edu.tr, ORCID ID: 0000-0002-9389-4984 [Makale kaylt tarihi: 20.02.2020-kabul tarihi: 20.09.2020; DOI: $10.29000 /$ rumelide.791380]
\end{abstract}




\begin{abstract}
in 1979, also addresses the adventure and crisis of the modern individual around social issues and traditional phenomena. In the novel, the author reveals the fears, conflicts, and mental states of the characters because of modern life. While doing all these, the author includes modernist novel concepts and themes in her work. In this sense, the novel tells dilemmas of the modern individual around the themes such as questioning, crisis, escape, loneliness, alienation, and uncertainty. In this study, Ayla Kutlu's novel Kaçıs has been examined in terms of themes specific to the modernist novel in the context of the reflections of modernism. The study first gives information about modernism, modernist art, and modernist novel and focuses on the content, expression, and technical features of the modernist novel. Then, it gives brief information about the author's art life and works and touches on her interest in the modernist novel. Following this, the study assesses the novel Kaçıs, which is the subject of the article, under various titles in the context of modernist themes. In the light of the findings in the conclusion part, it assesses the content and thematic aspect of the novel. Kaçıs, a novel in which the characters are in the center, is a work that reflects the psychological state and complex states of the modern individual(s) and processes them based on modernist themes such as escape, crisis, alienation, loneliness, questioning, uncertainty, non-communication, fear, and doubt.
\end{abstract}

Keywords: Ayla Kutlu, Kaçış (Escape), modernism, modernist novel, theme, individual

\title{
Giriş
}

Batı dünyasında sosyal, kültürel ve düşünsel bir arka planı olan modernizm, 1880'lerin sonlarından başlayarak 1940’lara kadar süren karmaşık ve özel bir dönem olarak adlandırllır. Sanatta, müzikte, mimaride ve edebiyatta 19. yüzyılın ikinci yarısından itibaren adından söz ettirmeye başlayan modernizm, 20. yüzyılın birinci yarısında oldukça etkili olmuştur. Özellikle I. Dünya Savaşı’nın insanlık üzerinde bıraktığı yıkım insanın acı çekmesine, bunalıma girmesine, içine kapanmasına neden olmuş ve bütün bunlar modernizmin doğuşunda rol oynamıştır. Modernizmi insanın kendisine sı̆̆ınılacak bir yer arayışı olarak gören Berman, kavramı "modern insanların modernleşmenin nesneleri oldukları kadar özneleri de olmak, modern dünyada sıkıca tutunabilecekleri bir yer bulmak ve kendilerini bu dünyada evde hissetmek için giriştikleri çabalar olarak" (2013: 11) açıklar. Genel manada geçmişe karşı şimdiki zamanın yüceltilmesini savunan modernizm, gelenekten bütünüyle kopuşu ifade eder. Bu bağlamda Gregory Jusdanis, gelenekle modernlik arasındaki kopukluğun modernleşme projesinin bir işlevi olduğunu belirtir. "[M]odernleşme projesinin modern toplumlardaki geleneksel unsurları tamamıyla ortadan kaldırdığını ters yönde de geleneksel toplumların hiçbir modern özellikleri olmadığını varsay[dığından]" gelenek ve modern kavramlarını "ayrı değil aralarında bir süreklilik olan, birbirlerine taban tabana zıt değil diyalektik biçimde bağlantılı olan kavramlar olarak” değerlendirir. Ona göre geleneksel yapılar, modernleşmeye kolayca teslim olmadıkları gibi yeni kurumlarla da iç içedir. "Ancak 'gecikmiş' toplumlar, geleneksel ve modern yapılar arasında bir huzursuzluk nöbeti yaşarlar” (1998: 14).

Modernizmin sanatla ilişkisine bakıldığında Childs ve Fowler, modernist sanatı, yaratımın yanı sıra parçalanmış, deneysel, biçim olarak karmaşık, eksiltili unsurları içeren ve gerçekçilik, materyalizm, geleneksel tür ve biçimden bu yana sanatçının özgürlük kavramlarıyla kültürel yıkım ve felaket kavramlarını ilişkilendirme eğiliminde olan bir yaklaşım olarak tanımlar (2006: 145). J. A. Cuddon da edebiyat söz konusu edildiğinde modernizmi, dikkat çeken biçim ve stil denemeleriyle insanın evrendeki durumunu, yerini ve işlevini yeni bakış açllarıyla ele almak için yerleşik kural, gelenek ve eğilimlerden kurtulmak olarak açıklar (2013: 442). Moretti'ye (2005: 3) göre ise modernizm "gerçek, açıklayıcı bir değeri olmayacak denli çelişik ya da belirsiz" bir kavramdır. Doğal olarak bu çelişki ve belirsizlik, "Sosyal hayatta ve insan ilişkilerinde görülen bu kaotik yapı, modernist edebiyata da yansımıştır. Özellikle 
dönemin şiiri ve romanları bu havadan etkilenerek geleneksel anlam ve yapı bütünlüğünden uzaklaşmış, karışık bir anlama ve yapıya sahip olmuşlardır” (Turan, 2016: 357). Bu anlamda diğer sanat dallarında olduğu gibi edebiyatta da modernizm, geleneksel yapı ve anlatımları reddederek yenilikçi biçimleri, farklı kurgulamaları, olağandışı anlatım teknikleri, bireysel izlekleri ve yepyeni dil/söylem biçimleriyle yaratma etkinliğine yeni bir soluk kazandırmış ve özgün bir sanat anlayışı olarak büyük bir ilgi görmüştür.

19. yüzyılın sonlarından itibaren etkisini gösteren modernist edebiyatla geleneksel edebiyat estetiğinden büyük bir kopuş yaşanmıştır. Özellikle modernist metinlerde, geleneksel temelli biçim, duyarlılık, içerik, teknik ve üslup özellikleri terk edilir. "Yeni estetik, bütünlügünü ve güvenilirliğini yitirmiş bu yeni dünyayı parçalara bölerek anlatmaktadır artık. (...) Göreceleşmiş zaman ise çizgisel akmamaktadır yeni metinlerde; dün-bugün-yarın alışılmadık bir biçimde birbirine karışır” (Ecevit, 2001: 29). Böylelikle modernist eserlerde geleneksel/gerçekçi edebiyatın temel dayanağı olan sürükleyici olay zinciri ortadan kalkar. İçerikten biçime, somuttan soyuta, dış dünyadan iç dünyaya ve bilince doğru bir yönelme olur. Bu yönelim zamanla roman türünün seyrini değiştirmiş, geleneksel/klasik romanın makul, düzenli, ahenkli ve sistemli yapısı yerini karmaşaya, düzensizliğe ve değer yitimine bırakmıştır (Çetin, 2003: 103). Yazarlar anlamakta güçlük çektikleri bu yeni gerçekliği, içerik/konu çevresinde öykülemenin imkânsızlığı karşısında, şimdiye kadar hiç denenmemiş yeni biçim arayışlarına girişmişlerdir.

Diğer taraftan bu eğilimin ortaya çıkışında psikoloji biliminin kurucularından William James ile psikanalizin kurucusu Sigmund Freud'un büyük etkisi olmuştur. Çünkü bu iki disiplin, yazarlar için "yeni bir dünyayı, insanın yeni ve farklı boyutunu, karmaşı ve derinlikli ruhsal zenginliklerini ortaya" (Çetin, 2003: 104) çıkarmada büyük rol oynamıştır. Bu roman anlayışıyla "Neden-sonuç ilişkisinin dışında grotesk/soyut bir düzlemde soluk alan, konusal bir bütünlük içermeyen bellek/bilinç yolculukları kurguluyordur yazar artık" (Ecevit 2001: 29). İçe dönük bir anlayışın benimsendiği modernist romanda bireyin öne çıkmasıyla ilgi, kişiler/karakterler üzerine yoğunlaşmış, özellikle başkişinin değişim süreci, duygusal serüveni, psikolojik durumları ve karmaşık hâlleri sebep sonuç ilişkisi içinde ele alınmıştır. Bu bağlamda Virginia Woolf, "Romancının ödevi[nin] ne denli bir sapma ve karmaşıklık gösterirse göstersin, bu değişken, bu bilinmez, sınırlanmış ruhu, dış öğelerle, dışsal olanla elinden geldiğince" (1964: 258-259) anlatmak olduğunu belirtir. Bu nedenle modern(ist) yazarların "ruhbilimin karanlık kuytuları[na]" (1964: 259) ilgi gösterdiklerini söyler. Bu bakımdan "Modern[ist] romancılara göre hayatın gerçekleri, bireylerin iç dünyalarının deşilmesiyle ortaya çıkar. Modern[ist] romanda gerçek kavramına yaklaşım geleneksel yaklaşımdan ayrışmıştır. Buna göre gerçek denilen şeyin kesin bir tanımı ve varlığı yoktur. Kişilere göre yorumlanan pek çok gerçek vardır” (Çetin, 2003: 105). Bu doğrultuda modernist roman, dış gerçekliği yansıtmaktan uzaklaşarak insanın iç gerçekliğine yönelir. Bireyin psikolojisini ve bilincini öne çıkararak onun bunalımını, huzursuzluğunu, karmaşasını, yalnızlığını, iletişimsizliğini, toplumdan kendisini soyutlanmasını ve varoluşsal sorgulamalarını anlatır. İnsanın bilincine, iç dünyasına temas edilirken bilinçaltına inilerek karmaşı serüveni gözler önüne serilir. Sevim Kantarcioğlu'na göre modernist romanda;

“insanın hem bilinci hem de bilinçaltı gerçekleri romanın konusu olmuştur. William James’in psikolojik zaman kavramı, geçmişin hâle yön verdiğini, hâlin bilinci ve tecrübenin ışığında değişmeye uğrayarak yaratıcı bir geleceğe doğru aktığını açıklamıştır. Bunun sonucu olarak izlenimci romanda geleneksel romanın kronolojik zaman anlayışı, yerini psikolojik zaman anlayışına bırakmıştır. İzlenimci romanın başkişisinin bilinç akışı (stream of consciousness) ve bu akışı oluşturan serbest çağrışımlar, romanın ham maddesini oluşturmuştur” (2007: 25).

Kantarcıoğlu’nun izlenimci roman olarak adlandırdığı modernist romanla birlikte anlatmaktan çok göstermenin, ne anlatıldığından ziyade nasıl anlatıldığının veya nasıl gösterildiğinin önem kazandığı 
deneysel ve yenilikçi bir anlayış belirir. Alegorik anlatım tarzına başvurulması, çağrışımlardan yararlanılması ve şiirsel dilin kullanılmasıyla geleneksel anlam ve yapı bütünlüğünden uzaklaşılır. Bu bakımdan modernist romanlarda realist anlatım yöntemleri bir kenara bırakılarak iç diyalog, iç monolog, bilinç akışı, mektup, laytmotif gibi anlatım teknikleri ağırlıklı olarak kullanılır. Bu yöntem ve tekniklerin kullanımıyla olay arka plana itilerek bireyin bilinci, bilinçaltı ve serbest çağrışımları çevresinde durumlar öne çıkarılır. Zamanda uzak/bütünsel (retrospection) ve anlık (flashback) (Sazyek, 2013: 246) geriye doğru kırılmaların olduğu bir kurgu düzeni ortaya çıkar. Böylelikle geleneksel anlam ve yapı bütünlüğünden kopan/koparılan roman, belirsizlikler içinde imgelere ve sembollere bürünerek bir çözümsüzlüğe doğru yol alır. Ecevit'e (2001: 48) göre "Modernist metinlerde anlamın çözümsüzleşmesi, açmaza girmesi, yazarın bilinçli olarak gerçekleştirdiği bir kurgu tekniğidir. (...) Tek bir odak anlamın olmadığı metinlerdir modernist romanlar. Yazar çeşitli tekniklerle anlamı/gerçekliği böler/çoğaltır/gizler."

Öte yandan geleneksel olanı reddetme tavrında olan ve dünyayı/yaşamı modernizmin yansımalarından hareketle yorumlayan modernist yazarlar "bireyin ruhsal bunalımını, arayışlarını, kentleşme oranının hızla arttığı dünyadaki yalnızlığını, varoluşsal sıkıntılarını, benlik sancılarını, sorgulamalarını, toplumdan kendini soyutlanmasını, çevreye yabancılaşmasını, iletişimsizliğini ve tutunamayışını çoklu anlatıcı ve bakış açlları ile birlikte 'yeni roman'a özgü anlatım teknikleri[yle]" (Şimşek, 2019: 183) anlatırlar. Roman türünün estetik bir yeri hak ettiğini düşünen Henry James, karakterlerin zihinlerine girerek onların zihinlerindeki karmaşıklığı ve sınırsızlığı ilk defa bu denli cesaretle anlatmaya girişen ilk romancı olarak dikkati çeker (Matz, 2004: 16). Batı edebiyatında Henry James ile birlikte Joseph Conrad, Marcel Proust, Virginia Woolf, James Joyce, Franz Kafka, William Faulkner gibi yazarlar modernist romanın öncüleri ve temsilcileri olarak kabul edilmektedir. Diğer yandan modernist romanın "modernizmin getirilerinden kimi yönleriyle yararlanırken aynı zamanda modernizm anlayışına bir eleştiri niteliğini de taşı[dığı]" (Yürek, 2008: 192) unutulmamalıdır. Zira siyasal, tarihsel ve toplumsal değişimlerin bir sonucu olarak ortaya çıkan modernizmin uygulamalarının modernist romanda zaman zaman kapalı bir şekilde eleştirildiği görülmektedir.

\section{Türk edebiyatında modernist roman}

Modernizm düşüncesinin sanata/edebiyata yansımasından itibaren Türk edebiyatında yazarlar geç de olsa modernist romana özgü kavramlara, izleklere, anlatım biçimlerine ve tekniklerine eserlerinde yer vermişlerdir. Türk kültürü ve edebiyatında şiire göre yeni bir tür olan roman, birkaç nitelikli eserler/metinler dışında Cumhuriyet’e kadar hem geleneksel çizgide hem de türün yeni oluşundan dolayı acemiliklerle örülmüss bir şekilde ilerler. Türk romanı, Cumhuriyet dönemiyle birlikte -özellikle 1930'lardan sonra- geleneksel ve modern[ist] unsurları bir arada kullanan bir yönde gelişir. Özellikle Peyami Safa, Abdülhak Şinasi Hisar, Ahmet Hamdi Tanpınar, Sait Faik Abasıyanık, Cevat Şakir Kabaağaçlı gibi bireye yönelen yazarlar, modernizm anlayışı çevresinde modernist romanın kimi unsurlarını, tekniklerini ve izleklerini eserlerinde bütünüyle olmasa da yansitırlar. Bu anlamda Türk romanında belirli süre geleneksel/yansıtıcı roman ile modernist romana özgü unsurlara birlikte yer verildiği söylenebilir.

Batıda modernist romanın temeli 180o'lü yılların sonlarında atılırken Türk edebiyatında modernizmin yansımalarına ve uygulamalarına 1940'tan sonra, daha bilinçli ve sistemli bir biçimde ise 1970'li yıllardan itibaren rastlanmaktadır. Bu bakımdan modernizmin yansımaları Türk edebiyatında hem geç olmuş hem de postmodernizmle aynı zaman aralıklarına denk gelmiştir. Ecevit'e (2001: 85) göre "gerçek anlamda modernist/postmodernist açılımlar, Türk edebiyatında yetmişli ylllarda kendini göstermeye 
başlar. Batılı romancının 190o'lerin ilk on yıllarında estetik düzlemde gerçekleştirdiği yenilikleri, Türk romancısı ilk kez yetmişli yıllarda metnine taşır. Türk edebiyatında, ellili ve altmışlı yılların toplumsal sorunlara çözüm arayan yaklaşımı, yetmişli yıllarda ortaya çıkan kimi metinlerde yerini daha öznel ve daha bireyci eğilimlere bırakmaya başlar”. Bu nedenle Türk edebiyatında modernist ve postmodernist unsurların kimi eserlerde birlikte ve geçişerek işlendiği söylenebilir. Yıldız Ecevit’in de işaret ettiği gibi "Türk edebiyatında modernist ve postmodernist özellikler, Batıda olduğu gibi, yüzyllı içine alan bir sürecin aşamaları olarak ortaya çıkmazlar. Yetmişli yıllarda Türk romanı ilk avangardist metinlerini üretmeye başladığında Batı avangardizmi postmodern düzlemde at oynatmaya başlamıştı bile. Bu nedenle, Türk romanının, önce modern sonra postmodern sırasına göre bir gelişme göstermesi de söz konusu olamazdı" (2001: 85).

Diğer yandan Kamil Yeşil, Türk edebiyatında modernist akımın çoğunlukla Franz Kafka, Albert Camus, Jean Paul Sartre ve Simone de Beauvoir'un etkisini taşıdığını ve bu yazarların eserlerinin de varoluşçuluğa bağlı olduğunu belirtir. Türk sanatçıları arasında varoluşçuluğun popüler olmasının sebebini de bu akımın burjuva ahlak anlayışına karşıt bir ahlak anlayışı ortaya koymasında ve burjuva toplumuna karşı isyancı yaklaşımı desteklemesinde görür. Ona göre, "Net bir politik ve ideolojik konuma sahip olmayan ve öznel anlamda kendilerini çevreleyen dünyadan nefret eden bu aydınlar, nesnel olarak, ortaya koydukları sanatla, tıpkı Avrupa modernistleri gibi, reddettikleri dünyanın bir parçası haline gelmişlerdir" (2011: 166). Bu bağlamda modernist anlayış, Türk edebiyatında özellikle Haldun Taner, Attila İlhan, Yusuf Atılgan, Orhan Duru, Ferit Edgü, Oğuz Atay, Adalet Ağaoğlu, Vüsat O. Bener, Rasim Özdenören, Bilge Karasu, Leyla Erbil, Nezihe Meriç, Füruzan, Nazlı Eray, Latife Tekin ve Orhan Pamuk gibi yazarların eserlerinde öne çıkan bir yaklaşım tarzı olur. Bu romancılar eliyle hem biçim hem de içerik bakımından modernist romana özgü unsurlara, izleklere ve tekniklere eserlerde yer verilir. Daha çok bireyin iç dünyasını anlatan bu yazarların eserlerinde, dramatik yöntemi esas alarak psikolojik tahlilleri ve bireysel izlekleri önceledikleri, zamanı geriye dönüşlerle kırılmalara uğrattıkları ve olaylardan çok durumları anlattıkları görülür. Metinlerinde dış gerçeklikten iç gerçekliğe yönelen bu romancılar, bireyi mensup oldukları kültür dairesi içinde değer ve değersizlikleriyle ortaya koyarlar. Onun bilincini, bunalımını, yalnızlığını, karmaşışını, yabancılaşmasını, ikilemini anlatırlar. Bunun yanında "Seksenli-doksanlı yıllarda Türk edebiyatında yenilikçi roman, çok boyutlu bir yayılım içine girer. Türk romanının önemli yazarlarından Adalet Agaoğlu'nun bu dönemde yayımladığı romanlarda modernist öğelere ağırlık verdiği görülür. Erhan Bener, Peride Celâl, Ahmet Altan, Nedim Gürsel, Selim İleri, Erendiz Atasu, Ayla Kutlu ve Buket Uzuner'in metinlerinde de aynı yıllarda gelenekseli aşan öğeler yoğunluk kazanır" (Ecevit, 2001: 92-93). Bu anlamda Ayla Kutlu da roman ve hikâyelerinde bireyi merkeze alarak onun bilincini, ruhsal değişimini ve toplum içindeki konumunu anlatması ve bu anlatımda modernist romana özgü izlekleri ve teknikleri kullanması açısından modernist romancılar arasında gösterilebilir.

\section{Ayla Kutlu'nun sanat yaşamı ve modernist romanla ilgisi}

14 Ağustos 1938'de Antakya'da doğan Ayla Kutlu'nun yazarlık serüveni, 1976'da Özgür İnsan dergisinde yayınlanan kitap tanıtım yazılarıyla başlar. Yazılarında Aygen Berel müstearını kullanan yazarın, aynı müstearla bu dergide öyküleri de yer alır. Daha sonra öyküleri Türk Dili, Sanat Olayı, Gösteri, Varlık gibi dergilerde çıkar. Bazı öyküleri Arapça, İngilizce, Almanca ve Flamanca gibi dillere çevrilir. 1980’de emekliye ayrılan Kutlu, düzenli bir şekilde edebî çalışmalarına ağırlık vererek eserlerini kaleme alır. Romanları sırasıyla Kaçış (1979), Islak Güneş (1980), Cadı Ağacı (1983), Tutsaklar (1983) [2004 yılındaki 2. baskısında Ateş Üstünde Yürümek adıyla yayınlanır], Bir Göçmen Kuştu O (1985), Hoşça Kal Umut (1987), Kadın Destanı (1994), Emir Beyin Kızlarl (1998), Asi... Asi... (2010) ve Yedinci 
Bayrak Urumeli'den İzmir'e (2016) adlarıyla yayımlanır. Hikâyeleri de HüsnüyusufGüzellemesi (1984), Sen de Gitme Triyandafilis (1990), Mekruh Kadınlar Mezarlı̆̆ (1995) ve Zehir Zlkkım Hikayeler (2001) isimleriyle kitaplaşır. Kutlu, 1985'te yayımlanan Bir Göçmen Kuştu O romanıyla 1986 Madarah Roman Ödülü’nü, Hoşça Kal Umut (1987) adlı romanıyla 1988 Mülkiyeliler Birliği Rüştü Koray Ödülü’nü alır. Aynı zamanda öykü türündeki eserleriyle de ödül alan yazar, 199o'da yayımlanan Sen De Gitme Triyandafilis kitabıyla aynı yıl Sait Faik Hikâye Ödülü’nü, 1995 tarihli Mekruh Kadınlar Mezarlığ ile 1996 Yunus Nadi Öykü Ödülü’nü kazanır. Diğer yandan Hoşça Kal Umut ve Cadı Ağacı romanları ile "İzinli”, "Sen de Gitme”, "Solgun Bir Sarı Gül” adını taşıyan öyküleri sinemaya uyarlanır (Kutlu, 1994: 8-25; Yalçın, 2010: 665-666). Ayrıca 9o'lı yılların başlarından itibaren çocuk edebiyatına da ilgi gösteren Kutlu'nun bu sahada masal, roman ve öykü türlerinde bilinen 18 eseri vardır.

Edebî eserlerini Türkiye'nin siyasal ve sosyal tarihini de içine alan bir dikkatle kurgulayan Kutlu'nun tarihsel süreçte meydana gelen toplumsal/siyasal olayları, durumları ve olguları bireysel konuları işlemek için âdeta araçsallaştırdığı görülür. Kendisi de bu durumu "Bütün yazdıklarımda, belli zaman parçaları fon olarak kullanılır. Toplumsaldan bireysele geçişte bu fon hem yardımcı olur hem de resmi tarih görüşü dışındaki bana göre gerçekliği okura iletmiş olurum” (Kutlu, 1994: 8) şeklinde ifade eder. Ayrıca "bütün bu zaman parçalarında ve seçtiğim tiplerde, kahramanlarda, günümüz insanı, onun acıları, haksızlığa uğramışlığı, anlaşılmamışlığı, anlatılmamışlığı var” (Kutlu, 1994: 9) diyerek romanlarının içeriğiyle ilgili ipucu verir. Bu bakımdan yazarın eserlerinin arka planında ülkenin yakın tarihinin yanı sıra çağının insanının acılarını, duygusal devinimlerini ve umutlarını 'geçmiş, şimdi ve gelecek' çizgisinde ele aldığı söylenebilir. Ayrıca yazarın "Niçin yazdığı?” sorusuna verdiği "Yüzyıllar boyunca kul olarak bırakılmış, kendini başka bir kimlikle değerlendirmesi öğretilmemiş ataerkil toplumun bireylerine, 'Sen insansın, hakların var. Görevlerin kadar bunları da önemsemelisin!' demek istiyorum. Bunu özellikle hatırlatmak istiyorum. Kulların kullarına yani insana kul diye bakınca onu araştırmak, onun üstüne düşünmek ve onu geliştirmek önemsenmiyor” (Karaca, 2006: 58-59) şeklindeki yanıtı da eserlerini bireyselleşme olgusu etrafında ve modern bireyin fark edilmesi bağlamında kaleme aldığını göstermektedir. Bu bakımdan Kutlu’nun kimi yönlerden modernist romana özgü bir anlayışla romanlarını yazdığı ve bireyi merkeze alarak onun hayat tecrübesini psikolojik durumlarından yola çıkarak anlattığı belirtilebilir.2 Onun eserlerinde Doğu-Batı, gelenek-modern iç içe geçerken toplumsallığa koşut olarak insanın varoluş serüveni bütün gizil yönleriyle belirginleşir. Yazar hakkında Erendüz Atasü’nün aşağıda verilen değerlendirmeleri de bu anlamda önemlidir:

\begin{abstract}
“Ayla Kutlu 'Şark’a bilgece bakar; Şark’ın insan varolușuna baktığı pencereden. Romancıya yakıșan da budur. Roman sanatının politika üstü kalması gerektiğinden filan değil; iktisadiden toplumsala, modernden geleneksele tüm 'görme biçimlerini' kapsayan çok geniş bir açı oluşturur, yazarın insanın varoluş serüvenine yönelen algılama ışınları da ondan. Doğunun insancıl sıcaklığı ışır bir bakışta; çamurlaşmaya başladığı noktaysa gözden kaçmaz. Ne hazin çelişkidir ki, bir yandan 'birey'i yüceltirken, son tahlilde 'ilke'lerden yani düşünsel soyutlanmalardan yana tavır koyan 'Garp' karşısında 'Şark’ın kaçınılmaz yenilgisine ulanan şekilsiz kaygan, kaypak yol, insancıllığın 'Şark’a özgü türünden başlamaktadır” (2015: 81-82).
\end{abstract}

Eserlerinde geleneksel ve modernist unsurlara birlikte yer verse de daha çok modernizme özgü kavramları ve izlekleri işlediği görülür. Bunun yanında modernist romanın anlatım olanaklarından ve tekniklerinden yararlanır. Yazarın eserlerinde bireyi öne çıkarması, olayları azaltarak durumlar üzerine

Ayla Kutlu'nun eserlerindeki kişiler genellikle kadınlardır. Yazar da kadın olmanın önsezisiyle kadınların duygu ve düşüncelerine kolaylıkla girmiş, onların bilinmeyen yanlarını gerçek yaşamla bağ kurarak kolayca aktarmıştır. Kurgusal metinleriyle kadınların toplumda var olduğunu ve isterlerse her alanda başarılı olabileceklerini göstermek istemiştir. Bu yüzden onun eserlerindeki bireyin gelişimi ve dönüşümü Türkiye'deki kadının değişimi ve gelişimiyle koşut görülebilir. Diğer romanlarından farklı olarak başkişinin erkek olduğu Kaçış romanında da Ayhan ve Ceren gibi özneleşmeye çalışan kadın karakterleri görmek mümkündür. 
yoğunlaşması, kurguda zamanı kırılmalara uğratması, geriye dönüşlerle parçalanmalara ve bölünmelere yer vermesi modernist romana eğilimini göstermektedir. Bu bağlamda anlatılarında bireysel izlekleri öncelediği görülen yazarın kaçış, kuşku, bunalım, belirsizlik, karmaşa, şüphe, aşk, sevgi, yabancılaşma, intihar, iletişimsizlik, çaresizlik, huzursuzluk, umutsuzluk, yitiriş gibi çoğu modernizmle ilişkili kavramlar üzerinde yoğunlaştı̆̆ görülür. Ayrıca modernist romana özgü anlatma olanaklarını (çoğul bakış açısı, çoğul anlatıcılar, alegorik anlatım, çağrışım) ve anlatım tekniklerini (iç diyalog, bilinç akışı, iç monolog, mektup, laytmotif) eserlerine uygulamaya çalışır. Dil konusundaki görüşlerini "Dilimi seviyorum, ona saygı gösteriyorum, sözcüklerin anlamlarını algılamaktan, imgeleri sözcüklerin içine doldurmaktan hoşlanıyorum. Yalın, kısa cümleleri yeğliyorum” (Kutlu, 1994: 10) şeklinde ifade eden yazarın imgesel dil tercihi de modernist romanın dil anlayışı dolayımında değerlendirilebilir. Bütün bu yönleriyle Kutlu'nun modernist romancılar arasında ele alınması yanlış olmayacaktır.

\title{
3. Kaçış’ta modernist izlekler
}

Ayla Kutlu'nun yayımlanan ilk romanı olan Kaçış, Milliyet gazetesinde 18 Temmuz-20 Aralık 1978 tarihleri arasında 121 sayı halinde tefrika edilmiştir. Daha sonra kitap olarak 1979'da Hür Yayınları aracılı̆̆ıyla yayımlanmıştır. ${ }^{3}$ Kutlu, 14 bölümden oluşan bu eseriyle Türkiye'nin belirli tarihsel dönemlerindeki gerçekliğini, 1950'li ve 1960'lı yılların Türkiye'sinin -özellikle 27 Mayıs 1960 ihtilali öncesi- çalkantılı ve karmaşık ortamını aydınlar üzerinden başarılı bir şekilde anlatmıştır. Fethi Naci, eseri "Kaçış, Türkiye'nin belirli bir anındaki gerçekliğini, küçük burjuva aydınlar açısından başarıyla anlatan bir roman. Bireyselle toplumsalın böylesine uyumlu bir bileşimini çok az romanda bulabiliyoruz" (2015: 539) diyerek değerlendirir. Attilâ Özkırımlı "bir aydının kendi kendisiyle hesaplaşmasının romanı" olarak gördüğü eseri "kendini arayışın, gerçek benliğini bulma uğraşının, çıkmazdan kurtulmaya çalışmanın öyküsü (aktaran Bezirci ve Taner, 2008: 460) olarak yorumlar. Bu bakımdan romanda Üstün karakteri etrafında bir aydının/akademisyenin bunalımını, ikilemini, ideolojik kaygılarını, huzursuzluğunu, karmaşasını ve yalnızlığını görmek mümkündür. Ayla Kutlu, öz yaşamıyla da ilişkilendirilen bu romanı hakkında esinlendiği kişiler ve olaylar bağlamında şunları söylemektedir:

\begin{abstract}
"Kaçış benim ilk romanım değil. Yayınlanan ilk romanım. Kaçış otobiyografik bir roman değil. Ayhan ben değilim. Benim bir sürü niteliğim ve yeteneğim Ayhan'da yok. Ayhan'ın nitelikleri de bende yok. Hele olay örgüsü... Ben anlaşan bir karı kocanın ikinci çocuğu olarak doğdum. Yaşamımda hiçbir olağan üstü olay olmadı. Düz bir çizgide gittim. Bu demek değil ki Kaçış’ta otobiyografik temalar yok. Elbette var. Ama bunlar öyküyü götürmüyor. Üstün'ün tutukluluk aylarını bir arkadaşım yaşamıştır. Üstün'ün yakalanışı saygı duyduğum bir profesörün yakalanışından esinlenir. Ayhan, Samandağ’ ından söz ederken benim çocukluk yıllarımda öyküden yararlanır ve o biçimde, yalan yanlış anlatır. Ana gerçekte benim anneannemdir. Ceren çok sevdiğim bir arkadaşımdır. Dahası Kaçış’ı artık kendimin göremiyorum. Onu bir kitapçı rafında gördüğüm an benden ayrı, benim dışında olduğunu anladım” (aktaran Bezirci ve Taner, 2008: 459-460).
\end{abstract}

Kutlu'nun söylediklerinden hareketle romanın yazarın kendi hayatını anlatmadığı fakat kişileri ve kişilerin başına gelen durumları aktarırken gerçek hayattaki tanıdıklarından ve tanıklıklarından esinlendiği, yararlandığı söylenebilir. Yazarın eserinde otobiyografik temaların varlı̆̆ından söz açması da romanın içeriği ve tematik yönüyle ilgili okura bir fikir verebilir. Çünkü otobiyografik temaların daha çok modern bireyin kurgulanmış benliğini, kimliğini yansıtmada kullanıldığı düşünüldüğünde romanın modern bireye ve onun bilinç dünyasına yöneldiği bir gerçektir. Bu anlamda belirgin bir mutsuzluk ve huzursuzluk içinde yaşamını sürdüren roman karakterlerinin hem aşk hem de insan ilişkilerinde huzursuzluğu ve mutsuzluğu sonuna kadar benliklerinde hissettikleri görülür. Diğer yandan Kutlu'nun

3 Yazıda eserin Bilgi Yayınevi’nden çıkan 2002 tarihli 3. Baskısı kullanılmıştır. 
anlatıya konumlandırdığı aydın karakterler, modern bireyin doğal çelişkilerini, karmaşık hâllerini ve umarsızlıklarını göstermesi açısından önemlidir. Bu karakterler, modernleşmenin nesneleri olmaktan slyrılarak birer özne olup kimlik kazanmaya çalışırlar. Ancak modernleşmenin dayatmalarından, modern hayat gereksinimlerinden ve modern-gelenek uyumsuzluğundan dolayı zaman zaman ikilemde kalırlar. Bu ikircikli ruh hâli, zamanla onları açmaza sokar, felaketlerle ve olumsuzluklara sürükler. Romanda daha çok Üstün ve Ayhan karakterleri üzerinden modern bireyin/aydının toplumdan ve toplumsal kurumlardan kendini soyutlaması, giderek topluma, çevresindekilere ve kendine yabancılaşması modernist romana özgü bir bakış açısıyla anlatılır. Aynı zamanda romanda "aşk kavramının bireye yönelik yıkıcı ve kendilik bilincine eriştirici özelliklerinin yüksek seviyede yansitıldı̆̆ı" (Çopur, 2018: 14) görülmektedir.

Bunun yanı sıra yazar Kaçış’ta, olayları ve durumları belli bir sıra dâhilinde anlatmaktansa modernist romana özgü bir duyarlılıkla kişilerin düşünceleri, arzuları, tasavvurları dolayımında bilincinden aktarır. Bu bakımdan romanda çoğul anlatıcının, çoğul bakış açısının ve yansıtıcı bilincin varlığından söz edilebilir. Yine anlatımda tercih edilen gösterme, mektup, bilinç akışı, iç monolog, iç diyalog, geriye dönüş gibi teknikler önem kazanır. Daha çok modernist yazarlar tarafından tercih edilen bu tekniklerin kullanımı, eserin modernist romanla ilgisini destekler. Aydın birey ve onun içsel sorgulamaları üzerinde duran yazar, kurguya dahil ettiği karakterleri modernist romana özgü izlekler etrafında anlatır. Kişiler özellikle çelişkiler sarmalı ve belirsizlikler içinde hareket ederler. Önlerini göremedikleri için sürekli bir mutsuzluk, huzursuzluk, tedirginlik ve umutsuzluk içinde oradan oraya savrulurlar. Uslu Kaya'ya (2017: 372) göre de "Kaçış, Türk edebiyatında entellektüel bir paranoya gibi karşımıza çıkar. Yalın bir ifade ile, aydın tutunamaz, bunalır ve kaçar. Kime ve neye kaçtığı belirsiz olsa da kaçışın yönü bellidir. Bizde entellektüel en çok kendinden kaçıp; yine en çok kendine kaçar/sı̆̆ınır” (Uslu Kaya, 2017: 372). Roman kişilerinin çelişkili ruh durumları ve karmaşık tutumları, sürekli bir çatışma ve bunalım hâlinde görünmelerine neden olur. Bu anlamda Kaçış’ta modernist romana özgü temel kavramların ve temaların öne çıktığı söylenebilir. Bu bakımdan eserde işlenen modernist izlekleri, romana ad olarak seçilen "kaçış" başta olmak üzere "bunalım”, “yabancılaşma”, "iletişimsizlik”, "kuşku”, “yalnızlık”, “çaresizlik”, "sorgulama", "korku” ve "belirsizlik" gibi başlıklar altında incelemek mümkündür.

\subsection{Kaçış}

Kaçış, insanın yaşadığı gerçeklikten uzaklaşarak kendi gerçekliğinden soyutlanarak yeni bir tutamak arayışı olarak açıklanabilir. Romanın isminden de yola çıkarak ilk olarak eserde modernizmin önemli kavramlarından "kaçış" izleğinin öne çıktığı görülmektedir. "Romanın adının Kaçış olarak belirlenmesi, eseri inşa eden ana izlekler ile anlamsal bağlamda koşut olması bakımından sembolik bir anlam taşır" (Çopur, 2018: 14). Romandaki kişiler çoğu zaman belirsizlik ve karmaşa içinde ilişkide oldukları kişilerden, bulundukları çevreden ve toplumdan kaçma, uzaklaşma arzusu taşırlar. Kimi zaman bu arzu başka birine sığınmaya dönüşür. Roman kişilerinden Üstün'ün hem Ayhan'a bağlanmamak hem de sakıncalı bulunan siyasi görüşü yüzünden Paris’e kaçışı, Ayhan’ın da Üstün'ün ülkeyi terk etmesinden sonra Cahit'le evlenmesi, evliliğinde arzu ettiği huzuru bulayıp kocası Cahit’ten uzaklaşması bu bağlamda okunabilir. Modern bireyin çıkmazda kalışı, kaçış izleği çevresinde bu üç karakter üzerinden anlatılır.

Söz gelimi romanın başkişisi Üstün, sol/sosyalist görüşlü bir akademisyendir. Adı siyasal olaylara karıştığından dolayı tedirginlik duymaktadır. Bir ortamda, çalıştığı üniversitede başka bir bölümde öğrenci olan Ayhan'la tanışmış ve aralarında duygusal bir yakınlık başlamıştır. Ancak Üstün, başlangıçta genç kıza karşı ilgisinin farkında değildir. Bir süre sonra hem onun hem de kendi duygularının farkına 
varınca Ayhan’a bağlanmak istemediğinden ondan uzaklaşmayı düşünür. Bağlanma, sevme, evlenme gibi şeyler, onun hayat anlayışına ters düşmektedir. Bu durumu modern bireyin karmaşık ruh hâli, gerçekleri, arzuları ve hayalleri çevresinde değerlendirmek mümkündür. Romanın başında eğitimi ve politik düşüncelerinden dolayı tutuklanmamak için Paris'e giden/kaçan Üstün, Fransa'da yaşamaya başladıktan sonra bu kaçışın/gidişin altında yatan diğer nedenleri de sorgular. Görünürde eğitimi ve politik düşüncelerinden dolayı tutuklanmamak için Paris'e giden Üstün'ün aslında Paris'e gidişinin önemli sebeplerinden biri de Ayhan'dan uzaklaşma isteğidir. Üstün, Türkiye'de bıraktığı Ayhan'ın kendisi için ne düşündüğünü ara sıra aklına getirmekte ancak kendine çeşitli bahaneler bularak avunmaktadır. O, görünürde hapse girmemek ve eğitim görmek için Paris'e gitse de arka planda Ayhan'a karşı duygusal bir bağllıktan çekindiği için bunu yapmıştır. Üstün, Paris’te kaldığı günlerde Ayhan'a aylardan beri yazmaya çalıştığı bir mektupta da bu gidişin/kaçışın asıl nedenini şöyle itiraf eder:

\begin{abstract}
“Aylardan beri bu mektubu yazıyorum sana. Paris'e geldiğimden beri. Belki buraya gelmeye karar verdiğimden, belki senden ayrılmayı düşünmeye başladığımdan beri. Aradan geçen bir yıldan bu yana, sana yazmayı düşündüğüm şeyler durmadan değişti.

Başlangıçta ne kadar kolay ve yalındı sana söyleyeceğim şeyler. Seni seviyordum. Senin mutlu olmanı istiyordum. Oysa yapmam gereken işler vardı ve seni ardımdan sürüklemem doğru olmazdı. Bunları seninle tartışmak istemedim. Çünkü beni haksız çıkaracağını biliyordum. Zaten bin güçlükle verdiğim kararın, senin bir sözün, bir davranışınla altüst olacağını biliyordum. Bunun için kaçtım senden. Bir süre acı çeksen bile, bu kaçışımdan ötürü beni bağışlamayacağını, ne kadar yadsımak istesen de gerçekte özlemini çektiğin huzurlu bir yaşama kavuşabileceğini düşündüğüm için senden kaçtığımı yazacaktım. Bunu böylece yazmanın, aslında kendi kendimle çelişkiye düşmek olduğunu bilerek, senin yine bana yanıldığımı söylemeni, beni geriye çağırmanı bekleyerek. Ama bunları yazamadım sana. Çelişkiye düşmüş olmaktan ya da küçük düşmekten korktuğum için değil. Günler geçtikçe, sana karsı duygularımın, bildiğimi sandığımdan değişik yapısını anlamaya başladım. Bu kaçış gerçekte kendimden kaçıştı. Sevgiden kaçıştı. Kendimi, inançlarımı yadsımaktan korkmaktı. Sonra, senin Cahit'le evlenmeye karar verdiğini öğrendim. Cahit’in mektubunu aldığım zaman...” (Kutlu, 2002: 6-7).
\end{abstract}

$\mathrm{Bu}$ anlamda Paris'e gidişinin/kaçışının nedenlerini devamlı olarak sorgulayan Üstün, bunun pek çok nedenin olduğunu belirtir. Kendince hiç inanmadığı halde birtakım bahaneler üreterek vicdanını rahatlatmak ister. Aynı mektubun devamında "Bir gün bu bağlılı̆ı̆, beni kendime karşı küçük düşürecek bir zayıflı̆̆a dönüşeceği, seni yitirmek korkusunun beni yolumdan çevirebilecek yoğunluğa ulaşacağı düşüncesi belki senden kaçışımın gerçek nedenidir” (Kutlu, 2002: 14) diyerek yaptığı şeyi kendince doğrulamaya çalışır. Bu bakımdan "Üstün’ün Fransa'ya gidişinin sadece akademik bir çaba değil; Ayhan’a olan bağlllığının ve sevgisinin Üstün'ü korkutması ve ondan uzak kalarak zaafını yenme çabasının bir sonucu olarak aşkından ve kendinden kaçış” (Çopur, 2018: 14) olarak okumak mümkündür. Ayrıca Üstün, Paris'e gittikten sonra burada Mireille adında genç bir kızla tanışmış, onunla da yakınlık kurmuştur. Ancak Üstün'ün Ayhan'la olan ilişkisinde duygusal bir bağ varken, Mireille'yle böyle bir bağ kuramadığı görülür. Mireille bu anlamda Üstün'ün Ayhan'dan uzaklaştıktan sonra sığındığı bir liman olarak görülebilir. Bu da Üstün'ün Ayhan'ı unutmak, ondan bütünüyle kaçmak için başkasıyla ilişki kurduğunu gösterir.

Romanın diğer önemli kişilerinden olan Ayhan da kaçış duygusunu yaşayanlar arasındadır. Ailesinden uzakta bir şehirde okuyan Ayhan, tek başına hayata tutunmaya çalışır. Onun hayata tutunma çabası ve yalnızlı̆̆ı modern bireyin yazgısıyla ilişkilendirilebilir. Romanda Üstün'ün Paris'e gitmesiyle duygusal bir boşluğa düşen ve yalnız kalan Ayhan, bir süre sonra hayatını, çok da sevmediği halde kendisine ilgi duyan Cahit'le birleştirmeye karar verir. Cahit aynı zamanda Üstün'ün okuldan iş arkadaşı bir akademisyendir. Ayhan biraz da kendini avutmak, sevdiği adamı unutmak ve yalnız kalmamak için bu evliliği kabullenir. Bir bakıma Cahit'e sığınarak Üstün'ün varlığından kaçar. Ancak evlilikten kısa bir süre sonra Üstün'ü unutamadığı ve Cahit’i bir türlü benimseyemediği için evli olmalarına rağmen ondan 
ayrılmayı düşünür. Kocasından kaçmaya, aynı evin içinde ondan uzak durmaya çalışır: "Cahit'i hırpalıyorum. Gözlerinin içine bakarak dinlemiyorum kendine sorun ettiği şeyleri. Sevişirken bile gözlerimi kapatıyorum. Bu kapatmanın hoşnutluktan olmadığını biliyor. Kendisinden kaçtığımı anlıyor" (Kutlu, 2002: 31-32). Sürekli kendini sorgulayan Ayhan, Üstün'ün Paris'e gitmesinden sonra kendi duygularını susturduğunu, onun kendisine yapmış olduğu haksızlıktan dolayı üzüldüğünü ve varlığından kaçmak, uzaklaşmak için hiç sorgulamadan Cahit'le evlendiğini itiraf eder: "Her şeyi yanlış değerlendiriyorum artık. Bir ağa düşüyormuş gibi düştüm. Düştüğümü biliyordum. Yine de bu ağ kurtarıcıydı. Boşluğa düşmekten iyi görünüyordu. Oysa daha az yıpranmış olsaydım, düşmezdim” (Kutlu, 2002: 32). Burada Ayhan evliliği, bir kaçış/kurtuluş olarak görmüş, ancak evlendikten sonra daha bir içine kapanmış, herkesten uzaklaşmış, en yakın arkadaşlarıyla dahi görüşmemiştir. Romanın ilerleyen bölümlerinde de Ayhan, bu kaçış isteğini sürdürür.

Son olarak roman kişilerinden Ceren de kaçış arzusu içinde olup onun kaçışı da tıpkı Ayhan'da olduğu gibi bir sığınmayı içinde barındırır. Ahmet ile evli olan Ceren, çocuklarının olmadığı için bir eksiklik hisseder. Bu durumu düşünmemek için çoğu zaman kendinden ve arzularından kaçar ve kendini avutabilecek şeylere sığınır. Bu bağlamda romanda kaçış izleğini bir sığınma arayışı olarak da değerlendirmek mümkündür. Zira roman kişileri çoğu olumsuzluklardan kaynaklanan durumlardan ve olaylardan dolayı kaçış arzusuna girerken aslında sığınabilecekleri bir liman veya kendilerini yanlarında iyi hissedebilecekleri insanı ararlar. Onun dünyasına/hayatına sığınmayı isterler. Ancak romanda çoğu kez bu kaçış ve sığınma arzusu olumsuzlukla sonuçlanır. Romanda karakterlerin bir yere ve bir şeye ait olamamaları, birilerine görünmekten çekinmeleri, sürekli bir kaçış hâli içinde olmaları modern bireyin yaşadığı sorunsalı yansıtması açısından önemlidir.

\subsection{Bunalım}

Modernist romanın temel izleklerinden olan bunalım, kişinin yaşadığı olumsuzluklardan dolayı kendine olan güvenini yitirmesi, karamsarlığa düşmesi ve umutsuzluğun artmasıyla ortaya çıkan ruhsal bozukluk ve çöküntü olarak tanımlanabilir. Romanda bunalım izleği zaman zaman krizler geçiren, psikolojik çatışmalar yaşayan Ayhan ile geçmişiyle ilgili pişmanlık ve vicdan azabı duyan Üstün üzerinden anlatılır. Özellikle çevresindekiler yüzünden kendine güvenini yitiren Ayhan, her şeyden umudunu keser ve hayatıyla ilgili endişe etmeye başlar. Bu endişe ve umutsuzluk benliğinde derin bir kırılmaya ve karmaşaya dönüşür. Hatalar yaptıkça daha çok ikilemde kalan Ayhan, hayatını bir türlü düzene koyamaz. İsteklerini gerçekleştiremediği ve çoğu şeyde hayal kırıklı̆̆ına uğradığı için zaman zaman bunalıma girer. Söz gelimi Cahit’le evliliğinde hayal kırıklı̆ı yaşayan Ayhan'ın geleceğiyle ilgili endişelerini ve yaşadığı iç sıkıntıyı gösteren iç konuşmasını bu bağlamda değerlendirmek mümkündür: "Herkesin şöyle ya da böyle düzeni kuruldu. Bense hiçbir şey yapmıyorum ya da yapamıyorum. Tam duruldum dediğimde bir rüzgâr çıkıyor. Başkaları algılamalarını akıllı uslu bir yerlere yerleştiriyorlar. Düzenli evleri gibi, düzenli iç yapılarıyla. Oysa ben? Karmakarışığım. (...) İtiyorum herkesi. Şu rüzgâr gibi... Yakınımdaki her şeyi çevirerek, kaydırarak, yerlerinden kopartarak, en kötüsü de sonunda ne yapacağımı bilmeyerek... (Kutlu, 2002: 28).

Üstün’ün Paris'e gitmesiyle duygusal bir boşluğa düşen ve bunalıma giren Ayhan, herkesten kaçıp uzaklara gitmeyi arzular. Hatta bu kaçış arzusu onda kimi zaman ölüm düşüncesini de içine alan bir kurtuluşu barındırır. Psikolojik olarak bir kırılma yaşayan Ayhan, yaşadığı kötü şeylerin sonlanması için kurtuluşu ölmekte görür. Yaşama dair olumsuz ve kötü şeylerden bütünüyle sıyrılıp kaçmak için ölüme bile razı olur: "Ölümü özledim. Doğru. Ölüme bile o tükenmeyen duygululuğum içinde gülünç şeyler ekliyorum. Ölüm sanki bir yer bir zaman aşamasıymış gibi. Bütün bağlarımdan bütün ilişkilerimden 
kurtaran, sonra yeniden ve istediğim bir yaşam türü olan bir olanak sanki ölüm” (Kutlu, 2002: 29). Bir süre sonra Ayhan, Cahit'le evlense de Üstün'ü unutmak için yaptığı bu evlilikte aradığı mutluluğu bulamaz: "Un ufak oldum. Cahit'e tutunduğumu sandım, ama onun da boynuna asılıp kendimle birlikte çekerek dibe kaydım. Hâlâ boğuluyorum” (Kutlu, 2002: 31). Bütün bunlara Cahit’in samimiyetsizliği ve kişisel hırsları da eklenince ondan tamamıyla soğur. Üstün’ü de bir türlü unutmadığından büyük bir huzursuzluk yaşar. Bir taraftan duyguları diğer taraftan Cahit’in baskıları onu bunalıma sokar. Aşağıda genç kadının düştüğü bunalım ve evliliği sırasında bilincinden geçenler iç konuşma tekniğiyle aktarılır:

\begin{abstract}
"Yaşamım, silinmeler içinde kısalıyor gibi. Yoğun duygulanımlardan sonra gelen ve sürüp giden boşluk, beni kendimden bile koparıyor. Üstün gittiğinden beri kendimi çok dinliyorum. İçimden çıkmaya çabaladıkça bir batağa saplanır gibi daha derinlerime kaçıyorum. Sanki Üstün'den önce bir yaşamım olmamış ve o giderken benim olan her şeyi beraberinde götürmüş gibi. Kendimi yeniden yaratıyormuş gibi inceden inceden dinliyorum; özenle, her yöne bakarak, her yerimi yoklayarak, kendimi dinlemeyi sürdürüyorum. İnsanlarla birlikte olmayı seven, bağıra çağıra şarkılar söyleyen Ayhan'ı diriltmeye çalışıyorum. Bir yıl oluyor, hiç şarkı söylemedim. (...) Onun gitmesinden beri sürekli olarak yanlışlıklar yapıyorum; yanlışlarımı onarmayı düşünüyorum, onarmaya başladığımda usanıyorum, olduğu gibi birakıyorum" (Kutlu, 2002: 31).
\end{abstract}

Ayrıca Cahit'le tartıştıkları yağmur bir gecede Ayhan'ın hissettikleri romanda “Yağmur yağıyor dışarda. Gitgide hızlanıyor. Artık yalnız kapalı havalarda deliren bir rüzgâr ve onu kovalayan sürekli yağmurlar yağacakmış gibi geliyor Ayhan'a” (Kutlu, 2002: 33) cümleleriyle verilir. Bir bakıma havanın durumu, yağmurun yağışı oldukça üzüntülü olan Ayhan'ın çaresizliğini, karamsarlığını ve parçalanmış iç dünyasını yansıtmaktadır. "Yağmurların dinginlik ve huzur getirmesi genel bir kanı olsa da kahramanın psikolojisinin durumu neticesinde iç karartıcı ya da kahramanın ruhundaki bunaltıyı açı̆̆a çıkartıcı bir özellik gösterir (Çopur, 2018: 20). Ayhan’a sürekli yağmur yağacakmış gibi gelmesi de genç kızın hayatıyla ilgili olumsuzlukların bitmeyeceğini düşünmesinden kaynaklanmaktadır.

Diğer taraftan romanda Üstün'ün geçmişiyle ilgili pişmanlıkları ve Ayhan'a yaptığı haksızlıklar karşısında duyduğu vicdan azabı, bunalım izleği çevresinde anlatılır. Üstün, cezaevinde kaldığı günlerde içinde bulunduğu durumdan kaynaklı olarak geçmişiyle yüzleşir. Bu yüzleşme esnasında vicdanıyla hesaplaşırken duyduğu pişmanlıklardan dolayı zaman zaman bunalıma girer. Örneğin Ayhan'ın aşkı ve aile olma fikri karşısında korkuya kapılan Üstün, Ayhan'la duygusal bir bağı olsa da evlilik gibi bir sorumluluğu taşıyamayacağı düşüncesiyle ondan uzaklaşmaya/ayrılmaya karar verir ve Paris'e gider. Ancak bu gidişi esnasında büyük bir vicdan azabını da yanında taşır. Geri dönüşlerle anlatılan bölümlerde ikilinin sohbetleri vasıtasıyla Ayhan'ın hamileliğini sonlandırdığı anlaşılır. Üstün’ün isteği ve baskısı yüzünden Ayhan, kürtajla cinsiyeti bile belli olan bebeğini aldırmıştır. Su adını verecekleri bebekleri, Üstün'ün sorumsuzluğu ve ailesinde gördüğü olumsuzluklar sebebiyle dünyaya gelememiştir.4 Bebeğini doğurma konusunda Ayhan'a düşüncesini sormayan ve ona bebeği aldırmak dışında çıkış yolu bırakmayan Üstün, bir süre sonra bu yaptıkları yüzünden vicdan azabı duymaya başlar. Özellikle hapishanede kaldığı günlerde yaptı̆̆ı bu kötülük onun peşini bırakmaz ve zihninde sanki bir ses/çağrışım gibi gezinir: "Bir imgeydi. Bir korku. Daha sonra Ayhan’ın telefon edip de her şeyin çok kolay olup bittiğini söylemesinden sonradır ki Su, yaşam boyu yüreğinden çıkaramayacağı bir ağırlıkla kendini duyurmaya başladı” (Kutlu, 2002: 146). Üstün korkuları, bencilliği ve

4 Üstün’ün annesi, oğlunun Ayhan'dan bir bebeği olacağını öğrenince evlenmesi için uyarıda bulunur. Annesi özellikle babasının kendisi için de böyle bir istekte bulunduğunu oğluna hatırlatır ve "Hiçbir kadın gönlüyle vazgeçmez çocuğundan. Düşün, babana kalsaydı, şimdi sen bir hela çukurunda çürümüş olacaktın..." (Kutlu, 2002: 146) der. Annesinin söylediklerinden hareketle Üstün’ün dünyaya gelmesini babasının istemediği ve bu nedenle çocukluktan gelen bir sevgi, şefkat eksikliği içinde olduğu anlaşılır. Üstün'ün çocukluğundan gelen ve benliğini sarsan bu durumun varlı̆̆ı, onun yanlış kararlar vermesine neden olur. Ayrıca Üstün'ün bir bebeğe ve aileye sahip olma korkusunun nedeni ailesindeki gördüğü/yaşadığı huzursuzlukların ve mutsuzlukların varlığıyla açıklanabilir. Bu nedenle kendi ailesinde şahit olduğu olumsuzluklar onun evlilikten, çocuk sahibi olmaktan korktuğunu göstermektedir. 
vurdumduymazlığı yüzünden hem bir bebeğin yaşamının sonlandırılmasına hem de kendisini seven bir kadının hayallerinin yıkılmasına yol açar. Bütün bunlar cezaevinde yalnız kaldığı anlarda Üstün'ün vicdanını, benliğini rahatsız eder ve zaman zaman bunalıma girmesine sebep olur.

Yine Üstün hapishanede kaldığı süre içinde kendisini ve Ayhan'a yaptıklarını sorgulamaya devam eder. Geçmişteki hatalarını ve özellikle Ayhan'a yaptığı haksızlıkları düşündükçe daha çok üzülür. Romanda başkişinin yaşadığı psikolojik kırılmalar romanda hapishanenin fiziki yapısıyla ilişkilendirilerek aktarılır: "Sırtını duvara dayamış, gözü demir kapıda. İçinde hafif bir ürperme var. Hava soğuk. Öteki tutuklular, ikili üçlü gruplar halinde volta atıyorlar bahçede. Bahçenin köşesinde kuru bir ağaç var. Taş duvarlarla çevrili küçücük avluda, bir ağacın yeşerebilmesi olanaksız geliyor. Burası yaşamla ölüm arasında asılı kalmış, gerçekliklerle düş arasında yapay bir ülke. Buraya bir kez kapatılan insanın, buradan çıksa bile, artık eskisi gibi olamayacağı belli bir şey.” (Kutlu, 2002: 151). Bir başka sefer de Üstün "Bağırmak geliyordu içinden. Beynindeki kargaşa duruluncaya kadar içmek, sızmak... Ama bunu yapamaz. Bir tutuklunun ruhsal bunalım geçirmesine izin verilmez” Kutlu 2002: 282) şeklinde düşünürken görülür. Bu bakımdan Çopur'un ifadesiyle "Hapishane, umutsuzluğu, güvensizliği ve korkuyu yansıtmaktadır. Üstün için çevresindeki objeler psikolojisinin yansıması olarak metaforik anlamda kötücül yapıya bürünürler ve mekânın labirentleşmesinde figüratif rol oynarlar” (2018: 21). Bu bakımdan hem fiziki hem düşünsel anlamda bireyin özgürlüğünün kısıtlandığı, güvensizliğin kol gezdiği hapishane, kişinin kendini sorgulamasını sağladığı gibi taşıdığı fiziksel özellikleri ve uyandırdığı çağrışımlar nedeniyle bireyin bunalım yaşadığı bir mekân özelliği de taşımaktadır.

\subsection{Yabancılaşma}

Kaçış’ta ele alınan modernist romana özgü başat izleklerden biri de yabancılaşmadır. Sazyek'e (2008: 17) göre "Yabancılaşma, on dokuzuncu yüzyılın ortalarından itibaren Batı toplumlarında; yirminci yüzyılın son çeyreğinden itibaren de ülkemiz büyük kentlerinde insanları oldukça derinden etkileyen, sarsan bir olgudur." Bu izlek, Türk edebiyatında özellikle modernist yazarların roman ve öykülerinde öne çıkmaktadır. Kaçış’ta yabancılaşma izleği, karakterlerin hem kendilerine ve çevresindekilere hem de topluma ve toplumun değerlerine yabancılaşmaları bağlamında işlenmiştir. Bu anlamda romanda yabancılaşma, daha çok Üstün ile Ayhan karakterleri üzerinden modern bireyin/aydının toplumdan ve toplumsal kurumlardan kendini soyutlaması, giderek çevresinden ve kendinden uzaklaşması bağlamında ele alınır. Yazar, bu sorununu dikkatlere sunarken roman kişilerinin davranışlarını ve tepkilerini modernist bakış açısıyla sunar. Özellikle iç konuşma, iç diyalog ve mektup gibi anlatım tekniklerine, kişilerin duygu ve düşüncelerini yansıtmak için sıkça başvurur. Diğer yandan roman kişilerinin yabancılaşma eğilimlerini güçsüzlük, anlamsızlık, kaygı, değersizlik, yalnızlık, küskünlük, karamsarlık gibi içinde bulundukları olumsuzluklar üzerinden okumak mümkündür. Genellikle kendilerine ve çevresindekilere yabancılaşmış olan bu karakterler, çoğu şeyden kendilerini soyutlayarak hayatlarına devam ederler. Sürekli bir belirsizlik, çaresizlik, mutsuzluk ve huzursuzluk içinde yaşarlar.

Romanda yabancılaşma izleği, ilk olarak evliliği, aile kurmayı yadırgayan, sevgi/aşk gibi duyguları önemsemeyen, baba olmak istemeyen, kişisel görüşleri ve bencilliğinden dolayı çevresindekilere ve topluma yabancılaşmış Üstün'ün davranışları ve düşünceleri çevresinde ele alınır. Örneğin Ayhan’ın kendisine karşı derin sevgisi ve bağllı̆̆ı karşısında, Üstün’ün genç kıza yazdı̆̆ı mektupların birinde sevgi ve sevmek üzerinde söyledikleri, modern bireyin bencilliği olarak görülebileceği gibi kişinin kendine, çevresine, değerlerine yabancılaşması bağlamında da okunabilir: "Bana ilk kez sevginin gücünden bahsettiğin zaman sana için için güldüğümü anımsıyorum. Sevgi, bir aldatmadan başka bir şey olamazdı. Aşk öyküleri, mutluluğu samanlıkta da elde edilebileceğine inananların düş gücünden 
doğmuş şeylerdi. Daha doğrusu, insanları bu yolla uyutup, uyuşturmak için kurnazca uydurulmuş tuzaklardı" (Kutlu, 2002: 18).

Yine romanda duygusal ilişkisinde ve evliliğinde umduğunu bulamadığı için içine kapanan Ayhan da belirgin bir yabancılaşma içinde hayatını sürdürmeye çalışır. Genç kadın, âşık olduğu Üstün'den ayrıldıktan sonra bir süre içine kapanır ve çevresinden kendisini soyutlar. Evi bir sığınak olarak gören Ayhan, kimseyle iletişime geçmez. Geçirdiği bunalım ve yaşadığı hayal kırıklıkları onun hem kendisine hem de çevresine yabancılaşmasına neden olur. Bundan kurtulmak için Cahit’in evlilik teklifini kabul etse de evliliğinde yaşadığı mutsuzluk/huzursuzluk bu yabancılaşmayı daha da derinleştirir. Bu bakımdan romanda bu sorun, bir süre evli kalan Ayhan ve Cahit'in ilişkileri ve onların çatışmaları çevresinde anlatılır. Cahit’le evli olmasına karşın Ayhan, Üstün'ü bir türlü unutamadığı için bu evliliği hem zihninde hem de yaşantısında oturtamaz. Kocasının davranışlarından, kendisine karşı tavırlarından rahatsızlık duymaya başlayınca birlikte yaşadıkları evi terk eder. Aşağıya alınan pasajda, Ayhan'ın konuşmak için Cerenlerin evine gelen kocasına karşı davranışları ve söylemleri bireyin kendine, çevresindekilere, değerlere ve aile kurumuna yabancılaşması bağlamında okunabilir:

\begin{abstract}
"Seni sevmiyorum. Hiçbir zaman da sevmedim. Senin bana sağladığın huzur var ya, ondan bile iğrendim. Yaşama biçimimizden, değer ölçülerinden, arkadaşlarından, onların karılarından... Yükselmek için kabullendiğin her şeyden... Suç belki sende, senin yapında değil. Ben başıboş bir insanım belki. Senin ölçülerine göre sorumsuzum. Senin ölçülerine göre erdemsizim. Üstün'ü seviyorum. Hep sevdim. Onun bana verdiği acıya, kırdığı onuruma ve bu yüzden seninle evlenmekte yaptığım yanlışlı̆ga karşın, o hep sevdiğim insandı. Çünkü onun varlığı bana soluk aldırıyor. Senin yanında ise... Boğuluyorum. Anlıyor musun?” (Kutlu, 2002: 222).
\end{abstract}

Duygusal anlamda derin bir kırılma yaşayan Ayhan, modern bireyin yaşadığı yabancılaşmayı hem psikolojik hem de toplumsal anlamda tecrübe ettiği görülür. Yaşadığı travmalar ve olumsuzluklar onu yıpratır ve yanlış kararlar vermesine sebep olur. Yabancılaşmanın etkisiyle evliliğe, aileye bakışında bir değersizlik ve yozlaşma ortaya çıkar. Bununla beraber, Ayhan'ın romanda Üstün'le bir türlü oturtamadığı ilişkisinden kaynaklanan kuşkularından dolayı zaman zaman kendine hatta kendi sesine bile yabancılaştığı da görülmektedir: "Üstün!.. Sinirli, yüksek tonda uzayıp incelen bir çığllk gibi bir çă̆ırıştı. Bu sesi tanıyamadım. Benim sesimdi. Tanıyamadım. Benden çıkarken bile beni yabancılayan bir sesti” (Kutlu, 2002: 271-272).

Öte yandan Ayhan'ın uzun bir aradan sonra Üstün'den gelen bir mektupla birlikte değişen ruh hâli ve beliren neşesi kendisini epeydir sarsan eskimişliği ve yabancılaşmayı üzerinden atması dolayımında aktarılır: “Odanın içindeki eşya, Ayhan'ın yürek vuruşlarına uyan tempoya kapılıyor. Her şey, Üstün gittiğinden beri evrende var olan eskimişliği, yabancllaşmayı üstünden atıyor. Bir yerlerde bir ateş silkiniyor, külünü savurup kızıl pırıltılar saçıyor. Bir bulut, tüm yükünü aşağıya salıyor. Toprak uyumaya hazırlanırken birden yeşil kahkahalarla gülmeye koyuluyor (...) yaptığı yanlışlığa gülüyor. Ayhan da gülüyor... küçük güneşler de...” (Kutlu, 2008: 76). O ana kadar kendine, kocasına ve çevresine yabancı olarak yaşayan genç kadın, Üstün'den gelen sözle birdenbire esenliğe kavuşsa da bu durum bir süreklilik göstermez. Bu davranışı, yabancılaşmanın kıskacındaki modern bireyin belirsizlik, çaresizlik ve yalnızlık gibi durumlardan uzaklaşmak adına gösterdiği olağan bir davranış olarak görmek mümkündür. Son olarak kişisel hırsları ve kariyer planları için bütün değerlerini hiçe sayan akademisyen Cahit de toplumsal düzeyde yabancılaşmanın merkezinde yer alan bir karakter olarak romanda yer alır. 


\title{
3.4. İletişimsizlik
}

Kaçış’ta etrafındakilerden tarafından anlaşılmayan, arzuları gerçekleşmeyen ve umutları tükenen kişilerin susma ve sessizlik edimlerini modernist romanın temel izleği iletişimsizlik bağlamında değerlendirmek mümkündür. Özellikle romanın merkezinde yer alan kişilerden Üstün, Ayhan ve Ceren çoğu kez suskunluklarıyla ve çevresindekilerle iletişime geçememeleriyle okurun karşısına çıkarlar. Modern yaşam içinde yaşadıkları mekânlarda ve kurdukları ilişkilerde hayal kırıklı̆̆ı yaşayan bu kişilerin kendi içlerine çekilerek sık sık suskunluk evresine girdikleri ve içlerine kapandıkları görülmektedir. Zaman zaman bu suskunluklarının nedenlerini, yaptıkları iç konuşmalarla veya yazdıkları ama çoğu gönderilmeyen mektuplarla dile getirirler. $\mathrm{Bu}$ anlamda romanda kişilerin sessizlikleri ve suskunlukları, onların iç döküşlerini içeren mektuplarla ve iç konuşmalarla sağlanır. Dolayısıyla bu konuşmalar ve mektuplar onların birbirlerine dile getiremediklerini ve itiraflarını da içerir. Yazar, özellikle mektup ve iç monolog tekniğiyle konuşamayan, iletişime geçemeyen karakterlerini konuşturur. Modernist roman iki önemli tekniği olan mektup ve iç konuşma teknikleri özellikle bireyin yaşadığı bunalımı, sıkılmış duygusunu ve var oluş sancılarını yansıtmada kullanılır. Aşağıda yaşadığı onca şey karşısında kendi ifade etmekten zorlanan ve roman boyunca derin bir sessizliğe gömülen Ayhan’ın iç döküşleriyle kendini nasıl ifade ettiği görülmektedir:

\begin{abstract}
"Yüz yüze geliyorlar. Bir çocuk oyunundaki gibi, uzun süre bakma yarışı yapar gibi birbirlerine bakıyorlar. Geceyi uzun ıslıklarla iki donmuş parçaya bölen bir tren geçiyor. Ayhan bu trenin aralarından geçtiğini, bundan böyle ne olursa olsun aynı yönde bulunmayacaklarını, aralarında uzun, soğuk bir ıslığın seslenip duracağını anlıyor. Birinden bir şeyler almanın kendisine bu kadar ağır geleceğini düşünmemiş şimdiye kadar. Bu duyguyla kalkıp pencereye yürüyor. Bu ölgün sarı ışıklar, bu kış başında ışıkların parıltısını solduran Ankara soğuğu, kimselerin geçmediği bir geceyi yaşayan sokak. Cahit’i yapayalnız bıraktığı düşüncesi ve o sevgi denen şey. Nedir sevgi? Nereden doğar, nerede sürdürür yaşamını, ne zaman bırakır insanı? Bir iz kalmadan yok olur gider? Yüreğinin çarpışını dinliyor: Önce dolgun bir tek vuruş... Sonra uzun bir süre susuyor. Susması rahatlık. Ardından bir vuruş daha geliyor...” (Kutlu 2002: 89-90).
\end{abstract}

Ayhan’ın karşısındakine söylemek isteyip de söyleyemedikleri ve “sevgi” üzerine düşündükleri böylece açığa çımış olur. Sessizliği tercih etmesi onun için kısa bir süre de olsa rahatlık ve esenlik kaynağı olmuştur. Bir bakıma sessizlik burada âdeta onun çaresizliğini gösteren bir çı̆̆lı̆̆a dönüşmüştür. Yine romanda Üstün cezaevine gönderilince Ayhan, üzüntüsünden dolayı kimseyle konuşmaz olur: "Üstün gittikten sonra bir akşam Cahit geldi yurda. Üstün'e ilişkin tek söz çıkmadı ağzından. O zamanlar herkesten kaçıyordum. Fevziye'yle bile konuşmak gelmiyordu (Kutlu 2002: 288). Genç kadının bu sessizlik hâli de modern bireyin suskunlukla var olma ve öz benliğini yansıtma arzusu çevresinde değerlendirilebilir.

\subsection{Sorgulama}

Kaçış'ta, öne çıkan temel izleklerden biri de sorgulamadır. Roman kişilerinin anlatının başından sonuna kadar süren sorgulamaları insanın varoluş kaygısını, bunalımını göstermesi ve toplumdaki konumlarını tartışmaya açması açısından önemlidir. Bu anlamda roman kişileri hem kendilerini hem de toplumun değer yargılarını sorgulayarak benliklerini ortaya koyarlar. Sorgulama izleğiyle bir bakıma kişilerin bütün yönlerinin okura gösterildiği söylenebilir. Aynı zamanda kişilerin sorgulamalarında iç konuşma, bilinç akışı, iç diyalog ve serbest çağrışım devreye girer. Böylece okur karakterlerin iç dünyasına ve bilinç altına bütünüyle vâkıf olur. İç sorgulamalar aynı zamanda karakterlerin var olma mücadelelerini ve kendi var oluşlarının anlamı üzerine düşündüklerini gösterir. 
Romanda başkişi Üstün hem bireysel dünyasında hem de sosyal yaşamında ilişkileri, kararları ve siyasal görüşleri dolayımında sürekli olarak kendisini sorgular. Aldığı kararları, yaptığı tercihleri ve gösterdiği davranışları değerlendirir. Örneğin Paris'e elinde olmayan nedenlerle gitmiş olsa da Ayhan'ı da terk ettiğinden orada yaşadığı süre zarfında bu yaptığını sorgulayarak genç kadının haklı olduğuna kanaat getirir: "Seni hep sevmek, sonra bırakıp giderek seni ve kendimi kurtaracağımı sanmak ne budalalıktı. Peki, şimdi neden dönüyorum sana?” (Kutlu, 2002: 10). Üstün, önce yaptığının yanlış olduğunu kabul ederek öz eleştiri yapar. Daha sonra neden döndüğünü bilmediğini söyleyerek çelişkili bir tutum sergiler ve kendisini sorgular: "Ama neden, sana yazmayı düşünür düşünmez kendimi haklı çıkarmaya çalışıyorum. Dahası, bu haklılığı savunurken üstü kapalı da olsa seni suçlu çıkarma çabasındayım?” (Kutlu, 2002: 17). Sürekli neden böyle yaptığını düşünüp sorgulayarak pişmanlığını da dile getirir: "Gerçekten de nasıl geçmişti bu bir yıl? Bir bakıma hiç yaşanmamış gibi, bir bakıma bir yll önce buraya gelen Üstün sanki o değil. Peki ne değişti bende? Paris bana ne verdi? Tezimi yazdım. Hem de bu kez akıllıca davrandım. Bilimselliğe yaslandım. Yeniden geri çevrilmemesi için açık kapı bırakmamaya çalıştım. Gerçekte, yine kendi kendimi kandırdığımın farkındayım” (Kutlu, 2000: 19). Üstün bu içsel sorgulamalarıyla ne istediği bilmeyen, kafa karışıklı̆̆ 1 yaşayan, ikilimde kalan ve duygusal anlamda karmaşa içinde olan bir birey olarak değerlendirilebilir.

Yine romanda Üstün gibi Ayhan da birtakım sorgulamalar içinde olup çoğu kez kendisini, kararlarını ve yaptıklarını değerlendirmektedir. Genç kadın başlarda Cahit ile neden evlendiğini bilmediğini söyler. Bu da onun tam olarak ne hissettiğini, neyi istediğini bilmediğini gösterir. Bu bakımdan Ayhan’ın ne yapacağı, hayatına nasıl yön vereceği tam olarak kestirilemez. Söz gelimi Cahit’ten ayrılma düşüncesini sorgulayan Ayhan, bunun kendinde ne zaman oluştuğunu bir türlü hatırlayamaz. Çoğu karmaşı düşüncelerini, çelişkili davranışlarını sorgulamalarla dile getirir. Üstün'e daha önce güvenini yitiren Ayhan, sevdiği adamın davranışlarını ve ilişkilerindeki tutumunu da sürekli olarak sorgulamaktadır. Bir ara cezaevine Üstün'ü görmeye giden Ayhan, "Hangi koşullar içinde olursa olsun, seni hep sevdiğimi unutmamanı istiyorum" diyen Üstün'ün söyledikleri karşısında "Neden inanmak gelmiyor içimden, neden inanmıyorum şimdi ona? Doğru mu söylüyor? Neden yalan söylesin? O hep güvendiğim değil miydi? Hiç yalan söylemedi ki bana" (Kutlu, 2002: 226) şeklinde bir sorgulamaya gider. Bu anlamda genç kadın, çok sevdiği, uğruna Cahit’i terk ettiği Üstün'e bile şüphe ile bakmakta ve geçmişte onunla yaşadıklarından dolayı sözlerinin doğruluğunu sorgulamaktadır. Sevdiği adamın doğruyu söyleyip söylemediğini kendine -belki de iç sesine- sorarak bir çıkış yolu arar. Ancak Ayhan, çoğu zaman bu sorgulamayı yaparken kendisinin farkında bile değildir. Belirsiz duygularla yaşamın ortasında savrulmakta ve hisleri yüzünden artık hata yapmaktan korkmaktadır. Belirsizlikler içinde bir hayatı sürdürmenin, birini sevmenin anlamsızlığı içinde kaybolur. Sevdiği adamın kendisini neden terk ettiğini, sevmediği bir adamla neden evlendiğini bu sorgulamalarla anlamaya çalışır. Bu sorgulamalar roman kişilerinin öğrenme ve belirsizlikleri ortadan kaldırma arzularını, geçmiş yaşantılarını ve duygularını yeniden gözden geçirmelerini içinde barındırır. Üstün de Ayhan da bir bilinmezin içinde kendilerini bulmaya çalışır. Çoğu zaman kendileri de sordukları soruların cevabını tam olarak bilmezler. Bu belirsizlik hâli onların kendilerini daha fazla sorgulamasına neden olur.

Karakterlerin korku ve şüphe çevresinde yaptıkları bu sorgulamalar, modern bireyin yaşadığı belirsizliği, karmaşayı ve kırılmayı göstermesi açısından önemlidir. Romanın özellikle aydın ve eğitimli denebilecek kişileri sürekli olarak bunalım ve psikolojik değişim içinde görünürler. Çoğu kez istekleri gerçekleşmeyince hayal kırıklı̆ı yaşarlar. Bu hayal kırıklıkları, kendilerini zamanla toplumdan ve çevrelerinden soyutlamalarına sebep olur. Kendilik bilinçlerini yitiren karakterlerin benliklerinde onulmaz yaralar açılır. Bu bağlamda Marshall Berman'ın modernizm düşüncesinin ve modern olmanın insanın kendisini biteviye eleştirme ve biteviye yenileme kapasitesi olduğunu ileri sürdüğü görüşlerini, 
roman kişilerinin durumunu anlamlandırması ve izah etmesi açısından burada belirtmek yerinde olacaktır:

\begin{abstract}
"Modem olmak, kişisel ve toplumsal yaşamı bir girdap deneyimi gibi yaşamak; insanın kendini ve dünyasını sürekli bir çözülüş, yenilenme, sıkıntı, kaygı, belirsizlik ve çelişki içinde bulması demektir. Kısaca, katı olan her şeyin ergiyip havaya karıştığı bir evrenin parçası olmak... Öte yandan bir modemist olmak, insanın kendini bu girdabın içinde bile bir șekilde evinde hissetmeyi bașarması, bu girdabın ritimlerini özümsemesi; bu girdabın akıntıları arasında, mahvedici akışının ortaya çıkmasına izin verdiği gerçeklik, güzellik, özgürlük ve adalet biçimleri arayışında olmak demektir" (2013: 460).
\end{abstract}

$\mathrm{Bu}$ bağlamda Kaçış’taki aydın karakterler, modernite-gelenek gerilimini deneyimledikleri kadar Berman'ın açıkladığı modern olma tecrübesinin getirdiği ruh hâlini sonuna kadar yaşarlar ve yaşamlarını sürekli olarak sorgulama yoluna giderler.

\title{
3.6. Kuşku
}

Romanda işlenen modernist kavramlardan/izleklerden biri de kuşkudur. Roman kişileri birbirleriyle ilişkilerinde güven ve itimat konusunda oldukça kuşkucudurlar. Çoğu kez karşılarındaki kişiye karşı güvensizlik hissederler ve kimi zaman da başkalarının iyi niyet ve amaçlarını kötüye yorarlar. $\mathrm{Bu}$ bakımdan modern bireyin genel bir özelliği olarak kuşku, romanda kendini hem bireysel hem de toplumsal ilişkilerde gösterir. Bazı yönleriyle topluma yabancılaşmış olan bu bireyler, hâliyle çevrelerinden kuşku duyarlar. İletişimde oldukları kişilerin davranışlarından ve yapıp etmelerinden dolayı güvensizlik içinde yaşarlar. Romanda kuşku izleği Ayhan-Üstün, Ayhan-Cahit ve Üstün-Cahit ilişkilerinde görülebileceği üzere insan ilişkileri çevresinde ele alınmıştır. Aynı zamanda bu izlek, toplumun bireye, devletin vatandaşa yaklaşımından hareketle de işlenmiştir.

Roman kişilerinin birbiriyle olan ilişkilerinden doğan kuşku, onları endişeye, üzüntüye ve ruhsal bir karmaşaya sürükler. Örneğin Ayhan ile Üstün arasındaki duygusal bağın karşılıklı bir güvene dayanmadığı görülür. Özellikle Ayhan, Üstün'ün yapıp etmelerinden dolayı hem duygularından hem de birlikte bir yaşam sürdüreceklerinden bir türlü emin olamaz. Zaten bir süre sonra duygusallığa hayatında yer vermemesi gerektiğini düşünen Üstün, başka şeyleri de bahane ederek Paris'e gider ve Ayhan’ı yüz üstü bırakır. Gerçek sevgide/aşkta güven olmasının gerekliliğini Ayhan "Gerçekte sevgi, karşılıksız sonsuz bir güven duygusuyla yeşerebilir” (Kutlu, 2002: 113) şeklinde dile getirir. Böylelikle genç kız, Üstün'le ilişkisindeki kuşkularının yersiz olmadı̆̆ını kavrar. Bunun yanında bir süre evli kalan Ayhan ve Cahit'in evliliklerinde de bir kuşku ve güvensizlik söz konusudur. Cahit her ne kadar evlenmeden önce Ayhan'ın Üstün'ü sevdiğini bilse de evlendikten sonra hâlâ onu düşünmesinden ve sevmesinden sürekli kuşku duyar. Bundan duyduğu rahatsızlığı davranışlarıyla gösterir. Diğer yandan Üstün de aynı üniversitede birlikte çalıştı̆̆ Cahit’in kariyer planları yaparken kendisini kıskanmasından ve aşırı hırslı olmasından dolayı kimi zaman şüpheye kapılır. Hatta bu şüphesi Cahit’in yurda dönen Üstün'ü ihbar etmesi ve tutuklattırmasıyla gerçeklik kazanır.

Yine romanda Demokrat Parti hükümetinin ve kolluk kuvvetlerinin solcular, sosyalistler üzerinde giderek artırdığı baskı, bu görüşe mensup kişileri sürekli tedirgin etmektedir. Özellikle Üstün ile Ahmet sürekli tutuklanacakları kaygısıyla kendilerini güvende hissetmezler. Devletin onlara dair kuşkuları yüzünden hayatlarını tam bir özgürlük içinde sürdüremezler. Kendilerini şikâyet edecekleri ve kullanacakları düşüncesiyle çevrelerindeki insanlardan ve karşılaştıkları kimselerden de kuşku duyarlar. Sürekli kendi içlerinde bu durumu düşünüp bilinçaltlarında bir karmaşa yaşarlar. Söz gelimi Üstün Paris’ten dönünce havaalanında gözaltına alınır ve emniyete götürülür. Üstün burada kendisine 
'Hocam' diye hitap eden polisleri karşısında görünce kendisini tanımalarından ötürü bir anda umutlansa da birden bu olumlu hava yerini kuşkuya bırakır: "Hükümet güç durumda. İktidarın ayaklarının altından kaydığını hissediyorlar. Muhalefet güçlü. Üniversiteler de seslerini yükseltmeye başladılar. Başbakan özellikle üniversite hocalarına kızıyor. Beni propagandaları için kullanmak isteyecekler. Dikkatli olmalıyım" (Kutlu, 2002: 55). Üstün'ün iç konuşmalarından özellikle devlet idaresine ve kolluk kuvvetine yönelik güvensizliği görmek mümkündür. Üstün bir ara Ahmet’in "Hükümetler içte ve dışta güçlüklerle karşılaştıkları zaman, halkın dikkatini başka yöne çekmek için komünist avı düzenlerler” (Kutlu, 2002: 63) deyişini anımsayınca "Ne demek istedikleri ortada. Birkaç gün sonra basında büyük başlıklarla, içinde bir üniversite öğretim üyesinin bulunduğu bir komünist şebekesinin ortaya çıarıldığı yazllacak" (Kutlu, 2002: 63) şeklinde bir eleştiri getirir. Halkına güven vermeyen bir devlet idaresi/otoritesiyle karşı karşıya olduğunu belirtir. Bu anlamda romandaki bu türden kuşku ve toplumdaki güvensizlik hâli kişiler üzerinde psikolojik travmalar yaratır. Romanda modern/aydın bireyin toplumla ve otoriteyle çatışması kuşku izleğiyle anlam kazanır. Bireyin otorite karşısındaki şüpheleri ve ona güvensizliği huzursuzluğun ve mutsuzluğun temel sebeplerinden biri olarak düşünülebilir.

\subsection{Yalnızlık}

Kişinin içinde yaşadığı dünyaya ve kendisine yabancılaşmış olduğunu bilmesi demek olan yalnızlık, insanın duygusunun en temel gerçeğidir (Paz, 1970: 104). Yalnızlık aynı zamanda bir yer yurt özlemi olarak da görülmekte ve bireyin ayrılmak zorunda kaldığı veya dışında bırakıldığı mekâna tekrar dönmek için duyduğu derin özlemi kapsamaktadır. Yalnızlık, yalnız olma ve hissetme hâli her ne kadar modern yaşamın bir meselesi olarak görülse de birey olma tarihi kadar eski bir durumdur. Klinik psikolojide yalnızlık, kendini yalnız hissetme anlamında kavramsallaştırılır ve iki tür yalnızlıktan bahsedilir. İlki, kişinin kalabalıklar içinde kendisini yalnız hissetmesi; yani varoluşsal yalnızlık, ikincisi ise sosyal ilişkiler bakımından yetersizlikten kaynaklanan kişilerarası yalnızlıktır (Bilgin, 2003: 422). Modern hayat, bireyi kalabalıkların içinde yalnızlaştırmış, bu nedenle kalabalıklardan uzakta tek başına yaşama düşüncesi çağın insanına hoş görünmüştür. Varoluşunu tartışan birey, yalnızlığını da sorgulayarak duygusal ve düşünsel bir krizin eşiğine gelmiştir. Kaçış’ta Üstün, Ayhan ve Ceren karakterlerinin yalnızlığını varoluşsal sorgulamalar içinde, insanlardan uzaklaşma, tek başına yaşama ve kendi ayakları üzerinde durma düşünceleri etrafında okumak mümkündür. Özellikle kişilerde görülen toplumdan, çevreden kendini soyutlayarak kabuğuna çekilme eğilimi, bir huzur arayışı olduğu kadar sorumluluktan kaçmayı da içinde barındırır. Dolayısıyla romanda yalnızlığın birey üzerinde yansımaları, kişilerin kimi zaman yalnız kalma arzuları kimi zaman da yalnızlıktan kurtulma çabaları etrafinda anlatılır.

Roman kişileri bir kimseye veya bir şeye bağlanarak yalnızlıktan kurtulmaya çalıştıkları gibi istekleri gerçekleşmeyince, beklentileri karşılanmayınca da yalnız kalmayı tercih ederler. Romanda Üstün, modernist romanın yalnızlığ içselleştiren, tercih eden karakterlerinden biri olarak düşünülebilir. Bir aydının, akademisyenin yalnızlı̆ını yaşayan Üstün, âdeta çevresine ve topluma yabancılaşmış bir halde varlığını sürdürür. Siyasi çalkantıların arasında kendini özgür hissedemez ve bu durum onu yavaş yavaş yalnızlığa iter. Ayhan'ın kendisinden beklentileri de (aşk, evlilik) onun sevdiklerinden uzaklaşmasına sebep olur. Bütün bu durumların etkisiyle eğitimini bahane ederek Fransa'ya gider. Paris'te kaldığı günlerde -ülkesinden ve Ayhan'dan uzak kalmanın da etkisiyle- tercih ettiği yalnızlık onu yavaş yavaş mutsuzluğa sürükler. Başta tercih ettiği yalnızlık duygusundan içten içe rahatsız olmaya başlar. Bu duygu hali onun kendisini sorgulamasina neden olur. Bu anlamda Üstün, Paris'te zaman zaman kalabalık bir kahvenin içinde tek başına otururken görünür. Ortam her ne kadar kalabalık olsa da ona 
içtiği birası, sigarası, okuduğu gazete ve henüz yazmayı bitirdiği bir mektup eşlik eder. "Kahveni içi kalabalık. Üstün, her zamanki köşesinde, yalnızlı̆̆ından biraz utanır gibi. Küçük mermer masanın üstünde bira bardağı, sigara tablası, 'Le Monde’u ve üstü yazılmış, pullanmış, kabarık bir mektup zarfı” (Kutlu, 2002: 6). Üstün’ün Paris'e giderek yalnızlığı tercih etmesi kendi seçimidir. Ayrıca bu yalnızlık hâli daha sonra bir kazanıma dönüşmüş; onun düşüncelerine ve hayata bakışına olumlu şekilde yansımıştır. Çünkü o, Paris'teki yalnızlık sürecinde hayatını, amaçlarını ve Ayhan’a olan sevgisini yeniden sorgulamış ve hayatıyla ilgili önemli kararlar almıştır. Diğer taraftan Paris’te bir pansiyonda kalan ve yalnız başına yaşayan Üstün'ün bundan kurtulmak için Mireille adlı Fransız bir genç kızla duygusal bir arkadaşlık kurduğu da görülmektedir. Bu ilişkisi başka bir ülkede yalnız yaşama kaygısını taşıdığı gibi Üstün’ün biraz da Ayhan'dan sonra kendisini avutmak için kurduğu bir münasebet olarak okunabilir. Zira Mirelille ile olan yakınlığına rağmen Üstün, yalnızlık duygusundan bir türlü kurtulamaz. Mireille kendisini sevmesine karşı Üstün, ona karşı duygusal bir yakınlık hissetmez. Bu durum Mireille ile yalnız kalmamak için görüştüğünü okura düşündürür. Bir anlamda ayrıksı ve uyumsuz yönleriyle dikkat çeken Üstün, modern bireyin 'kalabalıklar içindeki yalnızlığı'nı deneyimler. Ancak Üstün'ün bu yalnızlığı çoğu kez kendi isteğiyle yaşadığı da bir gerçektir.

Kişilerin birbirine duygularını, düşüncelerini ve iç döküşlerini mektuplarla ifade ettiği romanda Ayhan, Üstün hapisteyken sürekli geçmişe dalarak onla geçirdiği eski günleri anımsar. Bir gün evde otururken Üstün'le ayrı geçirdikleri ilk yaz tatilinde onun kendisine yazdığı mektubu bulur. Bu mektupta Üstün, yalnızlık duygusu içinde Ayhan’ özlediğini söyler. Şehirde birlikte gezdikleri yerlerde tek başına oturup bir şeyler yerken ondan uzak kalışından şöyle yakınır:

\begin{abstract}
"Karşımdaki masada çok genç bir çift oturuyor. Bütün gece boyunca, aşktan uyuyamamış gibi görünüyorlar. Kız eğilip oğlanın yanağını okşamak istiyor; oğlan benim bakışlarımdan rahatsız, başını kaçırıyor. Tedirginler. Benim yalnızlı̆̆ım yüzünden. Sen yanımda olsaydın, biz onları görmezdik. Ya da sen görürdün ama, sen onlara rahatlık verirdin. Ben, onlara değen gözlerimle seni özlemezdim. Daha yirmi dört saat olmadı senden ayrılalı. Günler geçecek... Bir de sana, özlem üzerine nutuklar atıyordum. Dün... Dün ne demek? Seni çok özleyeceğim kadar seni ardına almış bir zaman parçası demek" (Kutlu, 2002: 163-164).
\end{abstract}

Diğer taraftan romanda Ayhan, Üstün Paris'e gittikten sonra bir süre tek başına yaşamış, Üstün'ün kendisi önemsemediğini ve evlenme arzusunda olmadığını anlayınca geçmişinden sıyrılmak için Cahit’le evlenmiştir. Yalnız olmadığını çevresindekilere -özellikle Üstün’e- göstermek için yaptığı bu evlilik, yalnızlığına ve huzursuzluğuna çözüm olmamıştır: "Süregiden bir yalnızlık içindeyim. İçine girip kapandığım kozada kurumasını da bilmiyorum, kelebek olup uçmasını da...” (Kutlu, 2002: 33). Daha sonra Ayhan, Üstün'ün Türkiye'ye dönüşünde hapse girmesiyle Cahit’i terk eder ve tekrar onu düşünmeye başlar. Bu düşünceler içinde yağmurlu bir günde İstasyon'a doğru yürürken "Geniş T biçimi bir bulvarın ortasında yapayalnız olduğunu fark ed[er]". Ardından trenlerin gelmeyeceği anlarda "Her yan ıssız yalnız insanlar, sokaklar, bekleme yerleri. Evler de mi yalnızdır?” (Kutlu, 2002: 123) şeklinde bir sorgulamaya gider. Kaderini saran yalnızlı̆̆ın bütün evlerde de böyle olup olmadığını merak eder. Yine Ayhan, Üstün'ün hapiste olduğu dönemde yaşadığı yalnızlı̆̆ "Şimdi, bu tepedeki evde, bir başımayım artık. Kendimi tutuklu gibi duyuyorum. Çevremde varlığını duyuran tek şey gece ve gece de avucunun ortasından tutuyor beni. Sıkıştırıyor" (Kutlu, 2002: 276) diyerek anlatır. Romanın sonlarında Ayhan’ın ağzından aktarılan "Benim insansız yalnızlığım da Üstün’ün bir sürü insanla oluşan yalnızlı̆̆ı da aynı türden bir içe kapanmayı oluşturuyor” (Kutlu, 2002: 284) şeklindeki sözleriyle iki karakterin yalnızlık biçimleri âdeta tanımlanmış olur. 


\section{8. Çaresizlik}

Kişi odaklı durumların/olayların anlatımı sürüklediği romanda, işlenen başat izleklerinden biri de çaresizliktir. Romanda özellikle başkişi Üstün'le birlikte Ayhan, Cahit ve Ceren'in yaşadıklarından hareketle çaresizliğin sanki kişilerin kaderini çevreleyen bir olguya dönüştüğü görülmektedir. Yazar, romana dâhil ettiği ve kurguyu şekillendiren kişilerini karşı karşıya kaldıkları durumların da etkisiyle devamlı bir çaresizlik içinde gösterir. Bu çaresizlik hali onların içlerine kapanmalarına, bunalıma girmelerine sebep olur. Hatta kimi karakterler bir çıkar yol bulamayınca bulunduğu yeri terk etmeyi, hatta intiharı ve ölümü bile düşünür. Bazı erkek roman kişilerini de -özellikle Cahit’i- kabalığa ve şiddete sevk eder. Romanda bu izlek özellikle Üstün'ün Paris'e gidişiyle bir anda hayalleri yıkılan ve ne yapacă̆ını bilemeyen Ayhan'ın yaşadıkları, iç çekişleri ve düşündükleri çevresinde işlenir. Ayhan çaresizlik içinde kendinin avutmaya çalışır ve umarsızlığın bir sonucu olarak en sonunda istemeye istemeye Cahit'in evlilik teklifine olumlu cevap verir. Çaresiz kalışını da "Her şeyi yanlış değerlendiriyorum artık. Bir ağa düşüyormuş gibi düştüm. Düştüğümü biliyordum. Yine de bu ağ kurtarıcıydı. Boşluğa düşmekten iyi görünüyordu. Oysa daha az yıpranmış olsaydım, düşmezdim. Hâlâ düşüyorum. Hâlâ... Hiçbir ağ tutmuyor beni” (Kutlu, 2002: 32) şeklinde ifade eder. Bezirci'nin ifadesiyle "Bırakılmaktan, umarsızlıktan bunalan genç kız, Üstün'e olan kızgınlığının da etkisiyle teklifi kabul eder” (2008: 458). Ancak Cahit’te aradığı/arzuladığı mutluluğu, huzuru bulamaz. Aslında bu evliliği Üstün kendisini terk edip Paris'e gidince çaresiz kaldığı ve biraz da içine düştüğü boşluk nedeniyle yapmıştır. Kendisi de bu durumu şöyle itiraf etmektedir: "İpek böcekleri gibi doğanın ittiği yönden çıkamazdım ben. Kendime, bir kozanın içindekinden öte bir dünya oluşturamazdım. Öyle yaptım. Onun bıraktığı kozanın içinde ne dışarı çıkmayı ne de kıvrılıp ölmeyi biliyorum. Hiçbir eyleme girişmeksizin, kuruyorum: Yirmi dört yaşındayım daha. Yirmi dört yaşında, bir duygusal ölümü sürdürüyorum” (Kutlu, 2002: 33).

Diğer taraftan Ayhan'ın başkasını severek kendisiyle evlenmesinden olumsuz olarak etkilenen Cahit, karısının ilgisizliği ve sevgisizliği karşısında büyük bir çaresizlik içinde kıvranır. Romanda genç adamın çaresizliği “... ben seni seviyorum. Bu yüzden seni bırakamam. Sana olan bağımın yıllardan beri sürdüğünü bilirsin. Bir yıla yakın bir süredir karımsın. Sana sevgim azalmıyor, alışkanlığa dönüşmüyor. $\mathrm{Bu}$, benim elimde olan bir şey değil. Yenebileceğim bir duygu değil. Sense, bendeki yerini bir türlü anlamadın. Senin için neleri kabul ettiğimi, nelere boyun eğdiğimi görmemekte direndin” (Kutlu, 2002: 190) sözleriyle verilir. Cahit, Ayhan'ın gün geçtikçe artan ilgisizliği karşısında kabalaşmaya başlar. Karısının tutumunu değiştiremediği ve herhangi bir çözüm yolu bulamadığı için bir süre sonra onu döver. Ayhan için kocasıyla arasında daha önce sarsılmaya başlayan bağ, bu şiddet olayından sonra tamamıyla kopar. Bu bakımdan romanda çaresizliğin modern bireyleri ne ölçüde sarstığı ve çıkar yol bulamadıkları zamanlarda onları nasıl yanlış ve kötü şeylere sevk ettiği görülebilir.

\subsection{Korku}

Modern birey her şeyden önce korku ve kaygllarıyla yaşamakta, varlığı bu korkular sonucunda anlam kazanmaktadır. Kaçış'ta korku izleği bireylerin iç bunalımlarından ve bilinçaltı düşüncelerinden hareketle işlenmiştir. Romanın başından sonuna kadar hâkim olan bu izlek, kişilerin hayata dair kararlarında ve planlarında belirleyici olur. Roman kişileri, çoğu zaman korku ve endişeleriyle yüzleşir, bunun sonucunda bir kırılma yaşarlar. Kimi yalnız kalmaktan, kimi hapse girmekten kimi de sevdiğini bir daha görememekten endişe eder. Söz gelimi Üstün, Paris'e gittikten sonra en çok Ayhan'ın kendisini unutmasından korkar. Cahit'ten onunla evleneceğine dair bir mektup alınca bu korkusu daha da artar. Kendisine bile itiraf etmekte zorlandığı korkusunu Ayhan’a yazdığı bir mektupta dile getirir: 


\begin{abstract}
"Şimdi sana yazışımı bir çeşit ikiyüzlülük, bir fırsatçlık olarak nitelendirebilir misin? Burada işim bitti, dönüyorum ve seni yeniden sarsmaya, bunalımlara sürüklemeye çalışıyorum... Böyle diyebilir misin? Oysa ben, belki gerçek bitirişi arıyorum. Senden gerçekten kopabilmem için bu mektubu sana göndermem gerekli. Senin küçümsemeni bekliyorum. Ancak böyle anlayabilirim seni büsbütün yitirdiğimi. Ama korkuyorum. Şaşılacak şey. Aradan geçen bir yıl seni bana sanki unutturmuş gibi. Sana ‘siz’mi derdim, yoksa size ‘sen’ mi derdim, bunu bile düşünüyorum” (Kutlu, 2002: 7).
\end{abstract}

Yine romanda siyasi görüşlerinden dolayı tutuklanma endişesiyle Paris'e giden Üstün, Türkiye'de yaşarken sürekli bir korku yaşadığını ve bu sebeple hayatını rahat bir şekilde sürdüremediğinden yakınır: “Türkiye’de olsun, Paris’te olsun, sevdiği kişilerin başına gelmişti bu. Buraya gelmeden önce, aylarca, fakültede, yolda, evinde, her an kendisini karakola çağırmalarını beklediği olmuştu. Özellikle Ayhan'la buluştukları zaman, en küęük kuşkulu bir sesten nasıl tedirginlik duyduklarını anımsıyor" (Kutlu, 2002: 21). Üstün’ün korkuları bununla sınırlı kalmaz. Tutuklanma endişesini ülkesindeyken sürekli yaşadığını ve bu olasılı̆̆ın her zaman var olduğunu bilir. Paris'e gidişinin asıl sebebi olan bu korkusunu Ayhan'a ifade edemez. Korktuğu şeye sevdiği kadını da çekmekten endişe ettiğini belirtir: "Her düşündüğünde, içine baygınlık andıran bir eziklik veren bu olasılık, kendisi için doğru bildiği, yaşamına değer kazandırdığını düşündüğü bir yolda yürürken kaçınılması olanaksız bir tehlikeydi. Bunu bile bile her şeyi göze alıyordu. Ama kendisiyle birlikte Ayhan’ı da sürüklemekten korkuyordu” (Kutlu, 2002: 21).

Üstün'ün Paris'e gidişi bir nevi kaçışı korkuları nedeniyledir. Hem tutuklanma hem de Ayhan'a bağlanma korkusu onu böyle bir yola sevk eder. Her ne kadar hapse girmekten korktuğu için gittiğini belirtmiş olsa da romanda birkaç yerde Ayhan'a bağlanmaktan çekindiği için kaçtığını da söyler. Çünkü Üstün, bir kişiye sonsuza dek, tutkuyla kapılmak istemez ve bu korku yüzünden hem ondan hem de kendinden kaçmayı tercih eder. "En korktuğu şey buydu işte. Bu tutku. Bu tutkulu sevgi. Her şeyi bir sevgiye bağlamak" (Kutlu 2002: 65), “Onun sevgisinden korktuğum için kaçtım” (Kutlu, 2002: 158) gibi itiraf içeren sözleriyle korktuğunu dile getirir. Bunun yanı sıra Üstün, Paris’ten döneceği sıralarda Ayhan’a bir mektup yazar. Mektubu göndermeye cesaret edemediğinden bunun kararını arkadaşı Mireille'e bırakır. Hapse girdiğinde Mireille'nin mektubu göndermiş olduğunu düşünerek Ayhan'ın bundan zarar göreceğinden korkar. Ayrıca romanın sonunda bir kış akşamı hapisten çıkan Üstün'ün karanlık, ıssız sokaklarda sağa mı sola mı yürümesi gerektiğini düşünürken aslında koşmak istediğini ancak koşarsa, kendisinden kuşkulanacaklarını ve arkasından yetişip onu yeniden tutukevine geri götüreceklerinden korkar. Bu korku yüzünden en azından cezaevinin bulunduğu mahalleden uzaklaşana kadar sanki orada kalmamış gibi doğal bir şekilde yürümesi gerektiğini düşünür (Kutlu 2002: 291). Bütün bu yönleriyle değerlendirildiğinde Üstün'ün hayatının büsbütün korkular içinde geçtiği ve bu korkularının onda modern bireyin ikilemini, karmaşasını, bunalımını yansıttığı belirtilebilir.

Öte yandan romanda korkularıyla var olmaya çalışan bir başka karakter de Ayhan'dır. Ayhan'ın Üstün'le birlikteyken başlayan endişeleri, ondan ayrılması, sonrasında Cahit'le evlenmesi, Cahit'i terk etmesi, Üstün'ün ülkeye dönüşü ve tutuklanış süreci boyunca devam eder. Bu bakımdan Ayhan, modern bireyin yaşadığı kırılganlığı ve endişeyi bütün benliğinde hisseder. Romanın VI. bölümde Ayhan'ın Üstün'e yazdığı bir çeşit iç döküşünü, kendi kendisiyle hesaplaşmasını gösteren mektubunda onu çok görmek istemesine karşın Üstün'ün kendisini görünce onu yanlış bir şekilde değerlendireceğinden duyduğu korkuyu "Seni ne zaman görebileceğim? Korku? Evet... Seni görmeyi o kadar istiyorum, ama senin beni görmenden korkuyorum. Hani, 'benim bildiğim ben varken, senin bildiğin beni sevmezdim', demiştim. Yine aynı şey. Sana anlatacak çok şeyim var... Yine de sessiz soluksuz duracağım karşında. Beni aptal bulacağından bir kez daha korkacağım..." (Kutlu 2002: 127) şeklinde dile getirir. Yine romanda Ayhan, Üstün'ün hapishaneden çıkamama ihtimalini düşündükçe korkuya kapılır. Ayrıca Cahit’i terk edip Cerenlere taşındıktan sonra terk ettiği Cahit’in kendisini kolay bırakmayacağı düşüncesiyle korku içinde

Adres

Kurklareli Üniversitesi, Fen Edebiyat Fakültesi, Türk Dili ve Edebiyatı Bölümü, Kayalı Kampüsü-Kırklareli/TÜRKIYE e-posta: editor@rumelide.com 
yaşamını sürdürür. Ayhan bir bakıma bütün bu korkularıyla yüzleşerek hayata tutunmaya çalışır. Bu endişeleri kimi zaman onun bunalıma girmesine, hastalanmasına neden olur.

\subsection{Belirsizlik}

Kaçış’ta bir diğer modernist romana özgü izlek de belirsizliktir. Romanda özellikle kişilerin yaşamlarıyla ilgili belirsizlikler ve karmaşı noktalar dikkati çekmektedir. Karakterler âdeta yaşadıkları olumsuzluklardan dolayı oradan oraya savrulurken belirsizliğin kol gezdiği, kendilerini neyin beklediğini bilmedikleri bir dünyada yaşıyor gibidirler. Bir bölünmüşlüğün ve belgisizliğin içinde Berman'ın ifadesiyle "sürekli parçalanma ve yenilenmenin, mücadele ve çelişkinin, belirsizlik ve acının girdabına sürükle[nirler]” (2013: 27). Ne yapacakları, nasıl adım atacakları konusunda kararsızdırlar ve bu da onların yanlış kararlar vermesine neden olur. Aynı zamanda belirsizlikler kişileri sürekli olarak bir sorgulamaya yöneltir. Örneğin Üstün'ün Paris'e gidişinin nedenlerini bilmesine rağmen sürekli bunu sorgular. Sorguladıkça yaşadığı belirsizliklerden dolayı sürekli huzursuzluk yaşar. Dolayısıyla bu belirsizlik hâli, onu içsel bir buhrana sürükler. Kendini ifade ederken çelişkilere düşer.

Romanda belirsizlikler, Ayhan ve Cahit karakterleri için de geçerlidir. Ayhan öncelikle duygularıyla ilgili bir belirsizlik yaşar. Üstün kendisini terk edince Cahit’i sevip sevmediğinden emin olmadığı halde onunla evlenir. Çok geçmeden Cahit’le olan evliliğini ve hislerini sorgular. Kocasını, evini bırakıp belirsizlik içinde yaşamaya başlar. Hâlâ Üstün'ü unutamadığı için bunu yapar ancak bunu kendisine bile itiraf edemez. Diğer taraftan Ayhan Üstün'le ilgili düşünürken bulur kendini. Kendisini sevip sevmediğini, başka bir kadınla mutlu olup olmadığını sorgulayarak bir belirsizliğinin içinde çırpınır durur. Hâlâ yaşamında olduğunu ve onunla ilgili muğlak olan her şeyi bir an önce ortadan kaldırmak isteğiyle her gün biraz daha kötüye gider. “Üstün'ün yaşamından çıtığını sandığı gün” (Kutlu 2002: 19) cümlesiyle zihnindeki ve yaşamındaki belirsizliklerin başlangıcını itiraf etmiş olur. Anlatı boyunca Ayhan ve Üstün'le ilgili süreklilik gösteren bir belirsizlik söz konusudur. Bu anlamda "Ayhan ve Üstün'ün aşkları tam olarak başlamamış, adı konmamış, kahramanların içinde kalmış, dışa vurumu tepki bazında gerçekleşmiş bir aşktır. Dolayısıyla bu tam olarak olmamışlık ve adlandırılmamışlık, romanın entrik kurgusunu daha fazla güçlendirmiştir” (Yaşar, 2007: 22). Üstün ve Ayhan da aşklarının yarım kalmışlığı noktasında aynı düşüncede olup bunun anlamsızlığı üzerinde konuşlar ve bir netliğe kavuşturulması gerektiğini ifade ederler. "Sevgi bütünlüğe eriştiği zaman güzel ve haklıdır" (Kutlu, 2002: 6). Cahit de Ayhan ve Üstün arasında kalarak hayatını kurma ve aile olma konusunda bir belirsizliğin ortasında bulur kendini. Bu bakımdan romanda belirsizlikler kişileri sarıp sarmalar. Bu da roman kişilerinin zihinlerinin karışık olduğunu, belirsizlikler ve çelişkiler sarmalına düştüklerini gösterir.

Kişiler üzerinde oluşturulan bu belirsizlik, yazarın bilinçli bir tercihi olarak düşünülebilir. Zira belirsizlikler, sürekli olarak karakterler üzerinde korku, şüphe, güvensizlik ve karmaşa yaratır. Romanın sonunda karlı bir kış gecesi hapisten çıkan Üstün, elinde bavuluyla Ayhan'ın yaşadığı eve gider ve kapının zilini çalar. O günlerde yalnızlığına gömülen ve içine kapanan Ayhan, ev arkadaşı Ceren’in geldiğini düşünerek zilin çalmasını önemsemez. Üstün de kapı açılmayınca bavulunu yüklenip sokakta belli belirsiz bir yöne doğru yürümeye başlar. Kısa bir süre sonra Ayhan kapıdaki seslerin kesilmesiyle zili çalanın Ceren olmadığını anlar. Üstün'ün hapishaneden gönderdiği son mektupta bırakılma ihtimali olduğunu yazdığını hatırlayınca onun gelmiş olabileceğini düşünür. Bir süre odasında sessizliğin ve karanlığın içinde bu ihtimali zihninden geçirir. Ardından kapıyı kilitleyip kilitlemediğini kontrol etmek için koridora çıkar. Kilitlediğine emin olunca tekrar zilin çalıp çalmadığı kafasına takılır ve kapıyı açarak dışarıyı kontrol eder. Karlar üzerinde henüz silinmemiş ayak izlerini görünce Üstün’ün geldiğini anlar. 
Ardından Üstün’ün ayak izlerini takip ederek onu aramaya koyulur. "Ayhan, çıplak ayaklarının altında karların çatırdadığını fark etmiyor. Bedeninin ve karların savrulduğunu, ayaklarının kaydığını bilmiyor. Az sonra, ilerde bir yerlerde bir karartı göreceğine inanıyor. Bu umuda sarılmasını engelleyecek bir şey olamaz şu evrende. Hiçbir şey... Koşuyor, hızlanarak koşuyor” (Kutlu, 2002: 294). Roman, iki temel karakterin karlı bir kış gecesinde, sokakta nereye gittikleri bilmeden yürümeleriyle belirsizlik içinde son bulur. Romanın finalindeki bu bilinmezlik ve belirsizlik hâli de modernist romanın bir özelliği olarak değerlendirilebilir.

\section{Sonuç}

Ayla Kutlu'nun yayımlanan ilk romanı olan Kaçış, 1960 darbesi öncesinin siyasal olaylarının ve toplumsal karışıklıklarının fon olarak kullanıldığı, bir akademisyenin yaşadıklarından ve ilişkilerinden hareketle modern bireyin sorunlarının ve sorgulamalarının anlatıldığı bir eserdir. Arka planda düşünsel ve ideolojik özgürlüklere getirilen kısıtlamaların, adalet/yargı sisteminin eleştirildiği romanda psikolojik durumlar üzerinden bireyin bunalımı ve karmaşası işlenmiştir. Bu anlamda bir dönem romanı olarak değerlendirilen Kaçış’ta, bireyin yaşam macerasını, kültürel eğilimlerini ve modernlik deneyimlerini görmek mümkündür. Bilindiği gibi Türk romanında genellikle bireyin gelenek-modern arasındaki bocalayışı ve ikilemi bu ikilemi en çok yaşayan aydınlar üzerinden anlatılmıştır. Kutlu da romanında modernlik ve geleneksellik arasında bocalayan, yerleşik değer yargılarını tartışmaya açan Türk aydınının zihniyet dünyasını ve yaşadığı buhranı ele alır. Bu aydınların topluma, halka ve dünyaya bakışını gözler önüne serer. Romanda Üstün başta olmak üzere Ayhan, Cahit, Ceren gibi anlatı kişilerinin yaşantıları, duyguları, düşünceleri ve beklentileri etrafında modern bireyin açmazları üzerinde durulur. Bu kişiler birer aydın olarak ülkenin durumuyla ilgilenirken özgürlüklerinin kısıtlanmasıyla, hayal kırıklıklarına uğramalarıyla, özel ve iş yaşamlarında tutunamayışlarıyla ve varoluşsal sancllarıla görünürler. Kendilerini belirgin bir karamsarlık ve kötümserlik içinde ifade etmek zorunda kalırlar. Hem özel hem de çalışma hayatı içinde yalnızdırlar ve ruhsal bir çöküşe sürüklenir. Çoğu zaman ne yapacaklarını bilemezler ve korkularıyla yüzleşmek istemezler. Topluma ve çevreye yabancllaşan bu karakterler, cemiyetten uzaklaşma ve toplumdan kendilerini soyutlama arzusuyla hayatlarına devam ederler. Vazgeçmeye, terk etmeye meyilli olan bu kişiler, arzuladıkları şeyler konusunda hırslı ve kıskançtırlar ama yine de amaçlarına ulaşamazlar. Yoğun bir belirsizlik içinde hem kendilerini ve ilişkilerini hem de toplumun değer yargılarını sorgularlar.

Genel itibarıyla eserlerinde bireysel ve otobiyografik izleklere ağırlık veren Kutlu'nun Kaçış’ta modernizme özgü kavramlar, meseleler ve olgular dolayımında modernist romana özgü izleklere ağırlık verdiği söylenebilir. Böylece yazar; gelenek-modern, birey-toplum, akıl-duygu, sevgi-nefret, iyi-kötü, sevinç-keder gibi karşıtlıklar üzerinden kurguladığı romanında okura, kişilerin iç dünyalarını bütünüyle ve tüm açıklğıyla gösterme imkânı bulur. Eserde kişilerinin bunalımları, hayata tutunma mücadeleleri ve çaresizlikleri modernist romana özgü kavram ve izlekler etrafında anlatılır. Başta kaçış olmak üzere bunalım, yabancılaşma, yalnızlık, kuşku, sorgulama, korku, iletişimsizlik, çaresizlik, belirsizlik romanda öne çıkan izleklerdir. Romanda olay örgüsü bu kavramların ve izleklerin odağında ilerlerken kurgusal düzlem ve anlatım bu ögelerin sembolik değerleri etrafında oluşturulur. Yazar, bu izlekler aracılı̆̆ıyla bireyin psikolojik durumunu, içsel ve zihinsel macerasını ortaya koymayı amaçlar. Bu izleklerin işlenişiyle bireylerin zihinleri, düşünceleri, bilinçaltı gerçekleri bütünüyle orta çıkarılarak davranışlarının doğal ve psikolojik sebepleri gösterilir. Bunun yanında kişilerin hayat algıları, beklentileri, arzuları ortaya konularak modern bireyin savruluşu ve tutunamayışı ortaya konur. 
Diğer taraftan daha çok bireyin iç dünyasının anlatıldığı eserde, modernist anlayışın biçim ve içerik unsurlarıla birlikte anlatım tekniklerine de yer verilir. Eserde modernist romana özgü olarak anlatmadan ziyade gösterme yoluna gidilerek iç diyalog, iç monolog, bilinç akışı gibi modernist romanın başat anlatım teknikleri kullanılır. Son söz olarak Kaçış, kimi yönlerden modernist romanın ilkelerini bütünüyle taşımasa da özellikle üzerinde durulan kavramlar/meseleler, işlenen izlekler ve kullanılan anlatım teknikleri açısından Türk edebiyatında modernist romanın bir örneği olarak değerlendirilebilir. Ayrıca, bireyin merkeze alınarak modernist romana özgü kurgu, olay örgüsü, anlatıcı, bakış açısı özelliklerini taşıması açısından modernist romanın bir örneği olarak okunabilir.

\section{Kaynakça}

Atasü, Erendiz (2015). Benim Yazarlarım. İstanbul: Can.

Berman, Marshall (2013). Katı Olan Her Şey Buharlaşıyor. (Çev. Ümit Altuğ, Bülent Peker). İstanbul: İletişim.

Bezirci, A.- Taner, R. (2003). Seçme romanlar. (6. Baskı). İstanbul: Evrensel.

Bilgin, N. (2003). Sosyal Psikoloji Sözlüğü Kavramlar, Yaklaşımlar. İstanbul: Bağlam.

Çetin, N. (2003). Roman Çözümleme Yöntemi. Ankara: Öncü.

Childs, P.- Fowler, R. (2006). The Routledge Dictionary of Literary Terms. Abingdon: Routledge Publishing.

Çopur, Gürhan (2018). “Ayla Kutlu'nun Romanlarında Yapı ve İzlek”. Ardahan Üniversitesi Sosyal Bilimler Enstitüsü Doktora Tezi. Ardahan.

Cuddon, J. A. (2013). Dictionary of Literary Terms and Literary Theory, (5th Edition). Malden: WileyBlackwell Publishing, p. 441-442.

Ecevit, Y. (2001). Türk Romanında Postmodernist Açlımlar. İstanbul: İletişim.

Judanis, Gregory (1998). Gecikmiş Modernlik ve Estetik Kültür. (Çev. Tuncay Birkan). İstanbul: Metis..

Kantarcıŏglu, S. (2007). Türk ve Dünya Romanlarında Modernizm. İstanbul: Paradigma.

Karaca, T. N. (2006). Edebiyatımızın Kadın Kalemleri. Ankara: Vadi.

Kutlu, A. (1994). Kadın Destanı. Ankara: Bilgi.

Kutlu, A. (2002). Kaçış. Ankara: Bilgi.

Matz, J. (2004). The Modern Novel. Oxford: Blackwell Publishing.

Moretti, F. (2005). Modern Epik. (Çev. Nurçin İleri-Mehmet Murat Şahin). İstanbul: Agora Kitaplı̆̆ı.

Naci, F. (2015). 100 Yılın Yüz Türk Romanı. İstanbul: İş Bankası Kültür.

Paz, O. (1970). "Yalnızlı̆̆ın Diyalektiği”. (Çev. Bozkurt Güvenç). Yeni Dergi, S. 65, s.104-116.

Sazyek, H. (2008). Abdülhak Şinasi Hisar'ın Romanlarında Özel Yabancılaşma. Ankara: Akçağ.

Sazyek, H. (2013). Roman Terimleri Sözlüğü. Ankara: Hece.

Şimşek, Y. (2018). "Modernist Bir Roman Olarak Hiçbiryer”, Türük Uluslararası Dil, Edebiyat ve Halkbilimi Araştırmaları Dergisi, S. 15, s. 180-208.

Turan, Y. Z. (2016). "Modernist Roman Olarak As I Lay Dying \& Sessiz Ev”, Humanitas, S. 4(8), s. 353366.

Uslu Kaya, B. (2017). “Türk Romanında Safderun Alafranga, Ahlaksız Züppe, Kötücül Entelektüel”. Balıkesir Üniversitesi Sosyal Bilimler Enstitüsü Yayımlanmamış Doktora Tezi. Balıkesir.

Yalçın, M. (Ed.). (2010). Tanzimat'tan Bugüne Edebiyatçılar Ansiklopedisi II. İstanbul: Yapı Kredi Yayınları. 
Yaşar, Ş. (2007). “Ayla Kutlu'nun Roman ve Hikâyelerinde Yapı İncelemesi”. Gazi Üniversitesi Sosyal Bilimler Enstitüsü Yayımlanmamış Yüksek Lisans Tezi. Ankara.

Yeşil, Kâmil (2011). "Modernizmi Esas Alan Bir Yazar: Bilge Karasu, Modernist Bir Öykü: Odalardan Biri”, Yeni Türk Edebiyatı Araştırmaları, S. 5, s. 165-176.

Yürek, H. (2008). “Türk Romanında Modernist Etkinin Boyutları”, GÜ Gazi Eğitim Fakültesi Dergisi, S. 28 (1), s. 187-202.

Woolf, V. (1964). “Modern Roman”, Türk Dili- Roman Özel Sayısı II, (Çev. Akşit Göktürk), S. 159, s. 257260. 